OPEN ACCESS

Edited by:

Natalie Christina Steinel, University of Massachusetts Lowell, United States

Reviewed by: Yasmina Mohammed Abd EL-Hakim,

Zagazig University, Egypt Anoop Kumar,

National Institute of Pharmaceutical Education and Research, India

*Correspondence:

Hui Wang

huiwang@shsmu.edu.cn

Qian Ba

qba@shsmu.edu.cn Wenbo Yao

yaowenbo@sust.edu.cn

${ }^{\dagger}$ These authors have contributed equally to this work

Specialty section:

This article was submitted to Comparative Immunology, a section of the journal Frontiers in Immunology

Received: 15 April 2021 Accepted: 05 July 2021 Published: 20 July 2021

Citation:

Wang Z, Sun Y, Yao W, Ba Q and Wang $H$ (2021) Effects of Cadmium Exposure on the Immune

System and Immunoregulation.

Front. Immunol. 12:695484. doi: 10.3389/fimmu.2021.695484

\section{Effects of Cadmium Exposure on the Immune System and Immunoregulation}

\author{
Zhineng Wang ${ }^{1+}$, Ying Sun ${ }^{1+}$, Wenbo Yao ${ }^{1 *}$, Qian $\mathrm{Ba}^{2 *}$ and Hui Wang ${ }^{2 *}$ \\ ${ }^{1}$ School of Food and Biotechnological Engineering, Shaanxi University of Science and Technology, Xi'an, China, ${ }^{2}$ State Key \\ Laboratory of Oncogenes and Related Genes, Center for Single-Cell Omics, School of Public Health, Shanghai Jiao Tong \\ University School of Medicine, Shanghai, China
}

Cadmium (Cd), a biologically non-essential heavy metal, is widespread in the environment, including the air, water, and soil, and is widely present in foods and quantum dot preparations. Cd enters the body primarily through inhalation and ingestion. Its biological half-life in humans is 10-35 years; therefore, Cd poses long-term health risks. While most studies on $\mathrm{Cd}$ toxicity have focused on organ and tissue damage, the immunotoxicity of $\mathrm{Cd}$ has drawn increasing attention recently. $\mathrm{Cd}$ accumulates in immune cells, modulates the function of the immune system, triggers immunological responses, and leads to diverse health problems. Cd acts as an immunotoxic agent by regulating the activity and apoptosis of immune cells, altering the secretion of immune cytokines, inducing reactive oxygen species (ROS) production and oxidative stress, changing the frequency of $T$ lymphocyte subsets, and altering the production of selective antibodies in immune cells. This review summarizes the immunological toxicity of $\mathrm{Cd}$, elucidates the mechanisms underlying $\mathrm{Cd}$ toxicity in terms of innate immunity and adaptive immunity, and discusses potential strategies to alleviate the adverse effects of $\mathrm{Cd}$ on the immune system.

Keywords: immunoregulation, adaptive immunity, innate immunity, cadmium, toxicity

\footnotetext{
Abbreviations: Al, Aluminum; Akt, Protein kinase B; B-cells, B lymphocytes; Ca, Calcium; CAT, Catalase; Cd, Cadmium; CYPs, Cytochrome P450s; CREB1, cAMP responsive element binding protein 1; DCs, Dendritic cells; ERS, Endoplasmic reticulum stress; Fc $\gamma$ RIIB, Fc-gamma receptor II; Fe, Iron; GSH, Glutathione; HIF-1 $\alpha$, Hypoxia-inducible factor $1 \alpha$; IL, Interleukin; IARC, International Agency for Research on Cancer; IG, Immunoglobulin; IL-12p70, Interleukin-12 by LPSactivated; IFN, Interferon; $\mathrm{IP}_{3}$, Inositol 1,4,5-trisphosphate; Keap1, Kelch-like ECH-associated protein 1; LPS, Lipopolysaccharide; M1 macrophages, Classically activated macrophages; M2 macrophages, Alternatively activated macrophages; MAPK, Mitogen-activated protein kinase; MHC, Major histocompatibility complex; Na, Sodium; NLRP3,

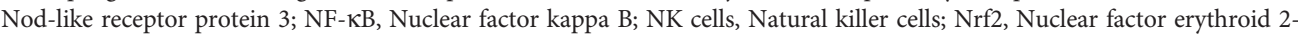
related factor 2; PFC, Plaque-forming cell; PI3K, Phosphoinositide 3-kinase; QHS, quantitative hemolysis; ROS, Reactive oxygen species; Se, Selenium; SOD, Superoxide dismutase; $\mathrm{H}_{2} \mathrm{~S}$, Hydrogen sulfide; TNF, Tumor necrosis factor; Th 1, T helper; T-cells, T lymphocytes; VDR, Vitamin D receptor; Zn, Zinc.
} 


\section{INTRODUCTION}

Heavy metal elements occur naturally in the environment as organic or inorganic compounds. In addition, heavy metals are released into the ambient air or sewage network in various industrial and combustion processes and are subsequently deposited in soil and water, where they enter the food chain and can pose human health risks $(1,2)$. Over the past century, industrialization has progressed at a rapid pace, which has greatly increased the demand for the exploitation of Earth's natural resources and led to global environmental pollution (3).

Cadmium (Cd), a heavy metal, originates from both natural and anthropogenic sources. Geological weathering is the primary natural source of $\mathrm{Cd}$, and anthropogenic sources include mining, smelting, wastewater irrigation, industrial and vehicular emissions, the deep burial of nickel-Cd batteries, manufacturing, and agrochemicals (4). In 1993, Cd was designated as a Class I carcinogen by the International Agency for Research on Cancer (IARC), and it is one of the worst heavy metal pollutants (5-7). It has no physiological function in the human body (8). Further, Cd cannot be metabolized by the human body and is difficult to excrete; as a result, it has a biological half-life of 10-35 years in humans (9). Humans are at high risk of $\mathrm{Cd}$ exposure through ingestion from water, grains, leafy vegetables, potatoes, and seafoods, as well as inhalation $(7,10)$. Occupational contact with Cd occurs primarily through respiration, whereas in the general population, $\mathrm{Cd}$ intake occurs primarily through food ingestion and recreational smoke inhalation $(2,11,12)$. In many countries, Cd levels in humans have been found to exceed the tolerance of various organs and are associated with increased risk of chronic diseases, such as cancer, diabetes, and osteoporosis (13). Cd accumulation occurs in several organs and tissues. Cd causes acute or chronic toxicity in the lungs, kidneys, liver, and bones and can be absorbed into the blood from the lungs and gastrointestinal tract, where it binds to blood cells, thus affecting the blood system (Figure 1 and Box 1) (5, 14-28).

$\mathrm{Cd}$ mainly induces damage through the production of free radicals, which affect the mitochondrial activity and can induce apoptosis (29). Cao et al. showed that Cd activates the mitochondria-mediated internal apoptosis pathway in BEAS2B cells, thus reducing their viability, causing reactive oxygen species (ROS) accumulation, inducing apoptosis, suppressing Bcell lymphoma-2 expression, and enhancing B-cell lymphoma-2associated X and cleaved caspase- 3 protein expression (12). Pathak et al. showed that Cd-treated splenocytes and thymocytes produce large amounts of ROS, which not only serve as a key mediator of Cd-induced apoptosis but also damage the mitochondrial membrane.

Heat shock proteins are general markers of cell stress. In nucleated blood cells, especially lymphocytes, $\mathrm{Cd}$ enhanced the transcription of metallothionein-IIA and heat shock protein 70 genes in time- and dose-dependent manners upon treatment with $\mathrm{CdCl}_{2}$ at concentrations from $5-50 \mu \mathrm{mol} / \mathrm{L}(1,30)$. In addition, Cd can directly damage DNA and disrupt the DNA repair process (16). As an efficient inducer of immune poisons and heat shock proteins, Cd triggers stress responses and exerts deleterious effects in immune cells (31).

(1) Cd accumulates in immune cells and dose-dependently induces apoptosis.

Chatterjee et al. showed that Cd treatment in Swiss albino mice (2.5-40 $\mu \mathrm{mol} / \mathrm{kg}$ body weight) led to dose-dependent $\mathrm{Cd}$ accumulation in splenocytes and induced apoptosis of splenic

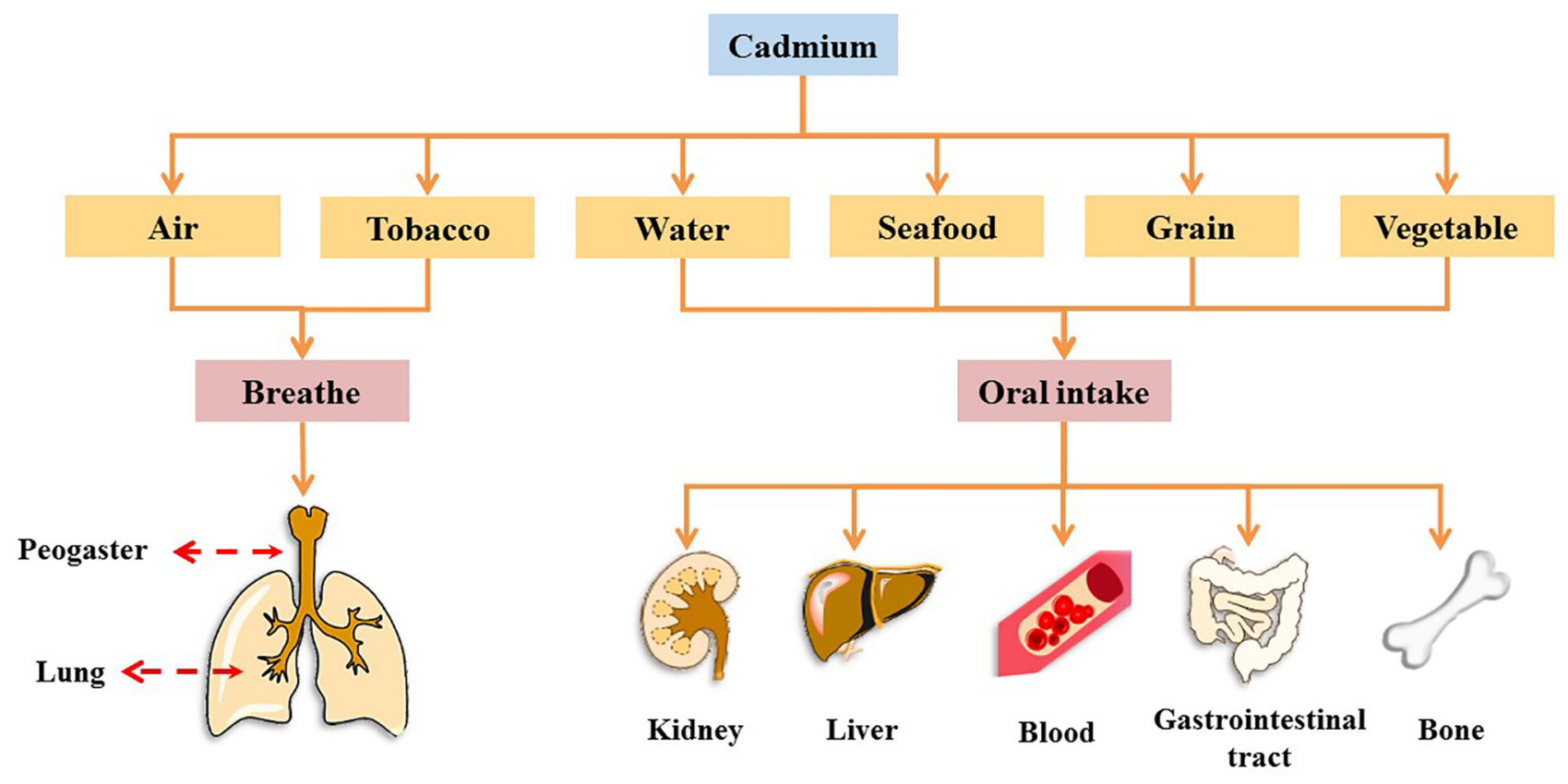

FIGURE 1 | Major routes of Cd exposure and toxic effects of $\mathrm{Cd}$ on different organs in the human body. 
BOX 1 | Effects of cadmium exposure on peogaster, lung, kidney, liver, blood, gastrointestinal tract, and bone.

1. Peogaster and lung

Studies have shown that the acute toxic properties of Cd were observed through the air-liquid-interface airway tissue models, which led to induce aberrant mucins expression and secretion, impaired cilia function, and squamous differentiation, thus impairing the function of the mucosal barrier in the lung and peogaster (14).

2. Kidney

Cd is a famous nephrotoxic substance. With Cd exposure, blood Cd in children, adolescents, and adults was positively associated with markers of kidney damage (as indicated by increased levels of $\mathrm{N}$-acetyl-b-D-glucosaminidase and b2-microglobulin) (15). Therefore, the current exposure to low levels of Cd may have caused adverse reactions in renal tubules.

3. LiverAfter

Cd induction, liver tissue was induced to have liver parenchyma with lymphocytes, fibrosis, microvesicular steatosis of the hepatocytes, hepatocellular microbubble fat degeneration, as well as many phagocytic cells, pyknotic cells, and vacuolation for $\mathrm{Cd}$, thus producing toxic effects on the liver (16).

4. Blood

Cd can interact with red blood cells, significantly reduce the activity of red blood cells superoxide dismutase and catalase, and increase the concentration of lipid peroxides (17).

5. Gastrointestinal tract

The gastrointestinal tract is one of the targets of $\mathrm{Cd}$ action and causes an acute inflammatory response in the intestines of mice, causing villus damage to the intestinal tissue and accompanying the immersion of inflammatory cells (18). In addition, in the intestinal inflammation caused by Cd exposure, Cd intake was observed to alter the structure of the gut microbiome and reduce the relative abundance of lactobacillus in the intestine $(19,20)$.

6. Bone

Cd exposure was associated with changes in bone metabolism and osteoporosis. There is growing evidence that Cd has a direct effect on osteoblasts, which accumulate and induce apoptosis in osteoblasts (21). As a result, Cd accumulation can have toxic effects on the bones, thereby reducing the density of bone minerals, regulating the expression of bone formation genes, affect the activity of osteoclasts and Ca absorption, thereby increasing the risk of osteoporosis $(22,23)$.

lymphocytes (32). Tsangaris et al. reported that Cd exposure induced apoptosis in the immune cell lines Raji, CCRF-CEM, and Molt-3 (30). Cd enters cells through the L-type calcium (Ca) channel, increases intracellular $\mathrm{Ca}$ concentrations, and binds to cytoplasmic and nuclear components, thus accumulates within cells $(1,33)$.

(2) Cd induces the differentiation of immune cells and changes the composition and proportion of lymphocyte subsets.

Desforges et al. found that $\mathrm{Cd}$ exposure affects the development of immune organs, differentiation of immune cells, and specific and non-specific immune responses in marine mammals (34). In mice, Cd exposure affects the composition and proportion of lymphocytes, including $\mathrm{CD} 4^{+}$, $\mathrm{CD} 8^{+}, \mathrm{CD} 25^{+}, \mathrm{CD} 44^{+}$, and $\mathrm{CD} 223^{+}$cells (35-37). In addition, Cd treatment reportedly promotes DNA synthesis, the adherence capacity of macrophages and lymphocytes, and cell proliferation. For example, human fibroblasts and prostatic epithelial cells exposed to low doses of Cd can develop into malignant cells $(38,39)$. This further suggests that Cd can interfere with normal immune system growth and development.

(3) Cd induces inflammatory responses in immune cells by activating multiple signaling pathways.

Micromolar concentrations of Cd activate multiple signaling pathways, in particular, the nuclear factor kappa B (NF- $\mathrm{KB})$ and mitogen-activated protein kinase (MAPK) pathways, in immune cells and induce the upregulation of inflammatory markers and mediators $(36,38,40)$. In addition, Cd can induce ROS production, cause mitochondrial injury, reduce antioxidant enzyme activity, induce the oxidative stress response, and activate endoplasmic reticulum stress (ERS) pathways, thereby playing a proinflammatory role in immune cells (41-48). Thus, $\mathrm{Cd}$ affects various cell functions, including the regulation of immune-cell activity and the secretion of cytokines in innate and adaptive immunity.

In recent years, $\mathrm{Cd}$ toxicity research has mostly focused on the toxic effects of $\mathrm{Cd}$ on different organs, while the effects of $\mathrm{Cd}$ exposure on immune function and its role in immune-system regulation should be comprehensively investigated. We provide an overview of the mechanisms of innate and adaptive $\mathrm{Cd}$ immunotoxicity to provide new insights into the effect of $\mathrm{Cd}$ exposure on immunity, as well as effective ways to alleviate Cd cytotoxicity.

\section{AND THE IMMUNE SYSTEM}

The immune system is a highly evolved biological system that is susceptible to environmental influences. While most new substances and microorganisms are often harmless, a small fraction of cases can pose a high risk (49). An effective immune system must be able to discriminate these instances by distinguishing self from non-self and harmless non-self from dangerous non-self (50). Therefore, the immune system is responsible for immunologic surveillance and defense, and immunoregulation. The immune system is a complex network of immune organs (bone marrow, spleen, lymph nodes, tonsils, and thymus, etc), immune cells (lymphocytes, macrophages, neutrophils, eosinophils, and basophilic cells, etc), and immune-active substances (antibodies, lysozymes, complement factors, immunoglobulins, interferons, and other cytokines, etc), in which immune cells communicate with each other through direct interaction or soluble cytokines (51).

The immune system is divided into innate immunity and adaptive immunity $(52,53)$. Innate immunity refers to the normal physiological defense function of the body. As the first 
line of host defense, it is fast and non-specific. Innate immune cells are activated by danger signals, including pathogens and risk-related molecular patterns as well as metabolite-related warning signs. Innate immune activation can promote tissue inflammation or immune resolution directly through phagocytosis and the secretion of biologically active molecules or indirectly through activating the adaptive immune response mediated by antigen-presenting cells (54). Innate immunity is activated in response to invasion by different pathogenic microorganisms and foreign bodies, thus protecting the host from infectious microorganisms (55). The adaptive immune response is antigen-specific and forms the second line of host defense. Adaptive immunity includes cell-mediated [T lymphocytes (T-cells)] and somolytic [B lymphocytes (B-cells)] immunity, which plays vital roles in driving tissue inflammation and repair (54). The $\mathrm{B}$-cell response is characterized by the production of antibodies, which play important roles in both innate and adaptive immunity. There are two types of B-cell immunity: T-cell-dependent and independent (56). The innate and adaptive immune systems work in concert to achieve the removal of senescent cells and defense against invading pathogens (57).

$\mathrm{Cd}$, as an immunotoxic inhibitor, interacts directly with immune cells and changes their status and functionality, thus damaging the immune system, in time- and dose-dependent manners (58). In what follows, we summarize the effects of Cd on innate and adaptive immune cells based on in vitro and in vivo experiments and the modes of action of $\mathrm{Cd}$ at different doses and exposure times (Tables 1, 2 and Figure 2).

\section{REGULATORY EFFECTS OF CD ON INNATE IMMUNITY}

Long-term exposure to low doses of $\mathrm{Cd}$ results in $\mathrm{Cd}$ accumulation in innate immune cells. Once Cd has entered the cell, it tends to occupy metal-binding protein domains, replacing essential metals (co-factors) in enzymes and thus inhibiting their ability to maintain cell function (2). However, apoptosis (programmed cell death) is an important feature of $\mathrm{Cd}$ toxicity. Many innate immune cells and mechanisms facilitate self- and non-self-recognition (80). Innate immune cells include monocytes, macrophages, neutrophils, natural killer (NK) cells, and dendritic cells (DCs) (2). Cd exposure affects multiple aspects of innate immunity by regulating innate immune responses, including chemokine expression and release $(5,81)$.

\section{Cd and Macrophages}

Macrophages function in identifying and eliminating non-self entities and thus play important roles in innate immunity and inflammation processes (60). Phagocytosis and endocytosis are regulated through specific receptors on the macrophage surface. In particular, the expression of Fc-gamma receptor II (Fc-RIIB) on the surface of macrophages is related to their immunoprotective function. $\mathrm{Wu}$ et al. reported that macrophages exposed to $\mathrm{Cd}$ in vitro have abnormal surface levels of Fc-RIIB, resulting in severe cell damage (60). In addition, Loose et al. showed that the phagocytic capacity of murine peritoneal and pulmonary alveolar macrophages was significantly reduced by $\mathrm{Cd}$ at concentrations of $8.0 \times 10^{-3}, 8.0 \times 10^{-2}$, and $8.0 \times 10^{-1} \mathrm{mg} / \mathrm{L}$ (59). Macrophages are classified as classically activated (M1) or alternatively activated (M2) based on their pro- or anti-inflammatory phenotype, respectively. The proportion of these two subtypes plays a crucial role in tissue inflammation, injury, and repair (82).

\section{Cd and M1 Macrophages}

In response to lipopolysaccharide (LPS) and Toll-like receptor signaling, M1 macrophages polarize and secrete a range of proinflammatory cytokines, such as interleukin (IL)-1 $\beta$, IL-23, IL-12, and tumor necrosis factor (TNF)- $\alpha$ (83). A recent study showed that LPS activates immunity-related processes in macrophages, whereas $\mathrm{Cd}$ inhibits these processes (62). An in-vivo study by Zhang et al. showed that $\mathrm{Cd}(20 \mu \mathrm{M}$ and $50 \mu \mathrm{M})$ dose-dependently caused morphological and ultrastructural damage in chicken peritoneal macrophages, ROS accumulation, and mitochondrial injury (46). Furthermore, Cd exposure inhibited the activity of chicken peritoneal macrophages and promoted the expression of IL- $1 \beta$, IL- 6 , and TNF- $\alpha$ in both inactivated macrophages and cells in response to LPS stimuli (46). Similarly, in mammals, long-term $\mathrm{Cd}$ exposure can result in reduced expression of cytokines, such as IL- 1 and TNF- $\alpha$, and inhibition of macrophage activity (72). These cytokines are produced by macrophages and can be used as markers for macrophage activity $(42,84)$. In addition, MAPK pathway activation and NF- $\kappa \mathrm{B}$-dependent gene expression can be used as indicators of macrophage proliferation, as demonstrated in an in-vitro study (5). In a study by Misra et al., Cd (1 $\mu \mathrm{M})$ induced DNA synthesis in macrophages, activated the MAPK and NF- $\kappa B$ signaling pathways, and promoted macrophage proliferation, thereby inducing a malignant phenotype (38). In fact, under complex pathological conditions, macrophages can exhibit mixed phenotypes and polarize to a predominant phenotype depending on the duration and stage of injury and/or repair. Larson-Casey et al. showed that following Cd (100 ng/kg)-induced lung injury in mice, lung macrophages polarized to a pro-inflammatory M1 phenotype (61). Cd-mediated mitochondrial ROS generation induced NF- $\mathrm{KB}$ activation, increased the expression of hypoxiainducible factor $1 \alpha$ (HIF-1 $\alpha$ ), and mediated the persistence of M1 lung macrophages to exacerbate lung injury (61). Choudhury et al. showed that in macrophages of Channa punctatus Bloch, Cd (1.96 $\mathrm{mg} / \mathrm{L}$ ) exposure induced inflammation by inhibiting the NF- $\mathrm{KB}$ pathway and altering nuclear factor erythroid 2-related factor 2 (Nrf2)-Kelch-like ECH-associated protein 1 (Keap1) signaling (73, 74). In-vitro experiments conducted by Cox et al. revealed that $\mathrm{Cd}$ $(0.1-100 \mu \mathrm{M})$ induced immune dysfunction in macrophages by inhibiting NF- $\kappa B$ signaling (62). Cd also induces macrophages to promote inflammation through activating protein kinase B (Akt)caspase-3 signaling (60) (Figure 2).

$\mathrm{Cd}$ accumulates and induces toxic effects in macrophages (85). Mouse osteoblasts exposed to Cd ( $1 \mathrm{mM})$ showed increased gene expression of macrophage migration inhibitory factor to prevent upregulation of macrophage growth factor expression, 
TABLE 1 | Effects of cadmium exposure on immune cells under experimental conditions in vitro.

\begin{tabular}{|c|c|c|c|c|c|c|}
\hline $\begin{array}{l}\text { Immune } \\
\text { system }\end{array}$ & Immune cell & Cell line & Cd dose & $\begin{array}{l}\text { Exposure } \\
\text { duration }\end{array}$ & Cellular effects & Reference \\
\hline \multirow[t]{12}{*}{$\begin{array}{l}\text { Innate } \\
\text { immunity }\end{array}$} & \multirow[t]{8}{*}{ Macrophages } & $\begin{array}{l}\text { Mice peritoneal } \\
\text { macrophages }\end{array}$ & $\begin{array}{l}8.0 \times 10^{-3} \mathrm{mg} / \mathrm{L} \\
8.0 \times 10^{-2} \mathrm{mg} / \mathrm{L} \\
8.0 \times 10^{-1} \mathrm{mg} / \mathrm{L}\end{array}$ & $30 \min$ & Phagocytic capacity was significantly reduced & (59) \\
\hline & & $\begin{array}{l}\text { Rat lung macrophage line } \\
\text { NR8383 cells }\end{array}$ & $10 \mu \mathrm{g} / \mathrm{mL}$ & $2 \mathrm{~h} ; 24 \mathrm{~h}$ & $\begin{array}{l}\text { The Fc-RIIB receptor level is abnormal and causes cell } \\
\text { damage }\end{array}$ & $(60)$ \\
\hline & & $\begin{array}{l}\text { Chicken peritoneal } \\
\text { macrophages }\end{array}$ & $20 \mu \mathrm{M} ; 50 \mu \mathrm{M}$ & $12 \mathrm{~h}$ & $\begin{array}{l}\text { Led to dose-dependent cytotoxicity and abnormal } \\
\text { immune response }\end{array}$ & $(46)$ \\
\hline & & $\begin{array}{l}\text { Mouse alveolar } \\
\text { macrophage } \\
\text { cell lines }\end{array}$ & $50 \mu \mathrm{M}$ & $3 \mathrm{~h}$ & $\begin{array}{l}\text { Promoted increased macrophage glycolytic function } \\
\text { with enhanced extracellular acidification rate, glycolytic } \\
\text { metabolites, and lactate excretion }\end{array}$ & $(61)$ \\
\hline & & $\begin{array}{l}\text { Human acute monocytic } \\
\text { leuke- } \\
\text { mic THP-1 cell line }\end{array}$ & $\begin{array}{c}0.1 \mu \mathrm{M} ; 1.0 \mu \mathrm{M} ; \\
2.5 \mu \mathrm{M} ; 5.0 \mu \mathrm{M} ; \\
10 \mu \mathrm{M} ; 20 \mu \mathrm{M} ; \\
40 \mu \mathrm{M} ; 100 \mu \mathrm{M}\end{array}$ & $4 \mathrm{~h}$ & $\begin{array}{l}\text { Cd results in immune dysfunction in macrophages } \\
\text { through inhibition of the } \\
N F-\kappa B \text { signaling pathway }\end{array}$ & $(62)$ \\
\hline & & $\begin{array}{l}\text { Mouse resident } \\
\text { peritoneal macrophages }\end{array}$ & $\begin{array}{c}5 \mu \mathrm{M} ; 10 \mu \mathrm{M} ; \\
20 \mu \mathrm{M} ; 30 \mu \mathrm{M} ; 40 \mu \mathrm{M} ; \\
50 \mu \mathrm{M}\end{array}$ & $18 \mathrm{~h}$ & $\begin{array}{l}\text { Cd produce an important impact on arachidonic acid } \\
\text { turnover in macrophages }\end{array}$ & $(63)$ \\
\hline & & $\begin{array}{l}\text { Murine macrophage-like } \\
\text { cell line RAW } 264.7\end{array}$ & $\begin{array}{c}0.1 \mathrm{mM} ; 0.3 \mathrm{mM} \\
1 \mathrm{mM} ; 3 \mathrm{mM}\end{array}$ & $24 \mathrm{~h}$ & $\begin{array}{l}\text { Cd exposure generated oxidative stress and } \\
\text { decreased the inflammatory responses }\end{array}$ & $(42)$ \\
\hline & & $\begin{array}{l}\text { Murine Macrophage Cell } \\
\text { Line RAW } 264.7\end{array}$ & $\begin{array}{c}0.01 \mu \mathrm{M} ; 0.1 \mu \mathrm{M} ; \\
10 \mu \mathrm{M}\end{array}$ & $2 \mathrm{~h}$ & $\begin{array}{l}\text { Cd alone caused a dose-dependent decreased viability } \\
\text { of exposed cells }\end{array}$ & $(64)$ \\
\hline & Mast cells & Mouse mast cell MC/9 & $\begin{array}{c}0.01 \mu \mathrm{M} ; 0.1 \mu \mathrm{M} \\
1 \mu \mathrm{M} ; 10 \mu \mathrm{M} \\
100 \mu \mathrm{M}\end{array}$ & $24 \mathrm{~h}$ & $\begin{array}{l}\text { Mast cells had full dose-response depletion of } \\
\text { glutathione below cytotoxic levels and mast cells } \\
\text { would be more susceptible to oxidative stress }\end{array}$ & $(65)$ \\
\hline & \multirow[t]{2}{*}{ Neutrophils } & Common carp neutrophils & $10 \mu \mathrm{M}$ & $2 \mathrm{~h}$ & $\begin{array}{l}\text { Cd-induced neutrophil apoptosis and } \\
\text { immunosuppression }\end{array}$ & $(44)$ \\
\hline & & chicken neutrophils & $10^{-6} \mathrm{M}$ & $\begin{array}{l}12 \text { h; } 24 \text { h; } \\
36 \text { h; } 48 \text { h }\end{array}$ & $\begin{array}{l}\text { Cd-induced immune suppression, inflammatory } \\
\text { response, and apoptosis via endoplasmic reticulum } \\
\text { stress }\end{array}$ & $(41)$ \\
\hline & $\begin{array}{l}\text { Natural killer } \\
(\mathrm{NK}) \text { cells }\end{array}$ & K562 cells & $100 \mu \mathrm{M}$ & $1 \mathrm{~h}$ & $\begin{array}{l}\text { Cd inhibited the cytotoxic activities of effector cells } \\
\text { prestimulated with IL-2, which mostly consist of NK } \\
\text { cells }\end{array}$ & $(66)$ \\
\hline \multirow[t]{10}{*}{$\begin{array}{l}\text { Adaptive } \\
\text { immunity }\end{array}$} & \multirow[t]{4}{*}{$\begin{array}{l}\text { T-lymphocyte } \\
\text { (T-cells) }\end{array}$} & $\begin{array}{l}\text { Male BALB/c mice } \\
\text { thymocyte }\end{array}$ & $\begin{array}{c}10 \mathrm{mM} ; 25 \mathrm{mM} ; \\
50 \mathrm{mM}\end{array}$ & $6 \mathrm{~h} ; 12 \mathrm{~h} ; 18 \mathrm{~h}$ & $\begin{array}{l}\text { Cd-induced T-cell apoptosis and changes the } \mathrm{CD}^{+} / \\
\mathrm{CD}^{+} \text {ratio }\end{array}$ & $(36)$ \\
\hline & & Mice spleen cells & $10 \mu \mathrm{M}$ & $24 \mathrm{~h}$ & Cd exposure suppresses the proliferation of T-cells & $(67)$ \\
\hline & & $\begin{array}{l}\text { T-cells were isolated from } \\
\text { healthy human }\end{array}$ & $\begin{array}{c}0.003 \mu \mathrm{M} ; 0.03 \mu \mathrm{M} ; \\
0.33 \mu \mathrm{M} ; 3.33 \mu \mathrm{M} ; \\
33.33 \mu \mathrm{M} ; 66.66 \mu \mathrm{M}\end{array}$ & $\begin{array}{l}20 \mathrm{~min} ; 40 \mathrm{~min} \\
60 \mathrm{~min} ; 90 \mathrm{~min} \\
120 \mathrm{~min}\end{array}$ & $\begin{array}{l}\text { cadmium depleted T lymphocytes GSH to a } \\
\text { harmful extent }\end{array}$ & $(68)$ \\
\hline & & $\begin{array}{l}\text { Peripheral blood } \\
\text { mononuclear cells were } \\
\text { isolated from healthy } \\
\text { donors }\end{array}$ & $\begin{array}{c}0.01334 \mu \mathrm{M} ; 0.04448 \\
\mu \mathrm{M} ; \\
0.1334 \mu \mathrm{M} ; 0.4448 \mu \mathrm{M} \\
1.334 \mu \mathrm{M} ; 4.448 \mu \mathrm{M} \\
13.34 \mu \mathrm{M} 44.48 \mu \mathrm{M} \\
133.4 \mu \mathrm{M} 444.8 \mu \mathrm{M}\end{array}$ & $24 \mathrm{~h}$ & $\begin{array}{l}\text { Cd polarizes the immune response toward type- } 2 \text { in } \\
\text { cells stimulated via T-cell receptors }\end{array}$ & (33) \\
\hline & \multirow{6}{*}{$\begin{array}{l}\text { B- } \\
\text { lymphocyte } \\
\text { (B-cells) }\end{array}$} & $\begin{array}{l}\text { Female DBA } 2 \mathrm{~J} \text { mice B- } \\
\text { cells }\end{array}$ & $\begin{array}{l}0.1 \mu \mathrm{M} ; 1 \mu \mathrm{M} ; 10 \mu \mathrm{M} \\
100 \mathrm{Mm} ; 10000 \mu \mathrm{M}\end{array}$ & $3 \mathrm{~h}$ & Cd has an early inhibitory effect on B-cell activation & (69) \\
\hline & & $\begin{array}{l}\text { Peripheral blood } \\
\text { mononuclear cells were } \\
\text { isolated from healthy adult }\end{array}$ & $5 \mu \mathrm{M} ; 25 \mu \mathrm{M} ; 50 \mu \mathrm{M}$ & $24 \mathrm{~h} ; 48 \mathrm{~h}$ & $\begin{array}{l}\text { Only lgE but not lgG synthesis of purified B-cells were } \\
\text { inhibited by Cd }\end{array}$ & $(1)$ \\
\hline & & $\begin{array}{l}\text { Peripheral blood } \\
\text { mononuclear cells were } \\
\text { isolated from healthy adult }\end{array}$ & $\begin{array}{c}0.01 \mu \mathrm{M} ; 0.1 \mu \mathrm{M} \\
1 \mu \mathrm{M} ; 2 \mu \mathrm{M} \\
5 \mu \mathrm{M} ; 10 \mu \mathrm{M}\end{array}$ & $\begin{array}{l}24 \mathrm{~h} ; 72 \mathrm{~h} ; \\
144 \mathrm{~h} \\
14 \mathrm{~d}\end{array}$ & $\begin{array}{l}\text { The viability of B-cells decreases with the increase of } \\
\text { Cd concentration }\end{array}$ & $(70)$ \\
\hline & & B-cell line Raji & $\begin{array}{c}5 \mu \mathrm{M} ; 10 \mu \mathrm{M} \\
15 \mu \mathrm{M} ; 20 \mu \mathrm{M} \\
25 \mu \mathrm{M} ; 30 \mu \mathrm{M} \\
35 \mu \mathrm{M} ; 40 \mu \mathrm{M} \\
50 \mu \mathrm{M} ; 75 \mu \mathrm{M} \\
100 \mu \mathrm{M}\end{array}$ & $18 \mathrm{~h}$ & $\begin{array}{l}\text { Cd-induced apoptosis in a dose-dependent manner in } \\
\text { the Raji B-cell line }\end{array}$ & $(30)$ \\
\hline & & Human Ramos B cells & $\begin{array}{l}0.1 \mu \mathrm{M} ; 1 \mu \mathrm{M} \\
2.5 \mu \mathrm{M} ; 5 \mu \mathrm{M}\end{array}$ & $24 \mathrm{~h}$ & $\begin{array}{l}\text { Cd exposure induced apoptosis, which was } \\
\text { dependent on Cd-induced vacuole membrane protein } \\
1 \text { expression and autophagy }\end{array}$ & $(71)$ \\
\hline & & $\begin{array}{l}\text { B-cells were isolated from } \\
\text { healthy human volunteer } \\
\text { blood sample }\end{array}$ & $\begin{array}{c}0.003 \mu \mathrm{M} ; 0.03 \mu \mathrm{M} ; \\
0.33 \mu \mathrm{M} ; 3.33 \mu \mathrm{M} ; \\
33.33 \mu \mathrm{M} ; 66.66 \mu \mathrm{M}\end{array}$ & $\begin{array}{l}20 \mathrm{~min} ; 40 \mathrm{~min} ; \\
60 \mathrm{~min} ; 90 \mathrm{~min} ; \\
120 \mathrm{~min}\end{array}$ & $\begin{array}{l}\text { cadmium depleted B lymphocytes GSH to a } \\
\text { harmful extent }\end{array}$ & (68) \\
\hline
\end{tabular}


TABLE 2 | Effects of cadmium exposure on immune cells under experimental conditions in vivo.

\begin{tabular}{|c|c|c|c|c|c|c|}
\hline $\begin{array}{l}\text { Immune } \\
\text { system }\end{array}$ & Immune cell & Animal & Cd dose & $\begin{array}{l}\text { Exposure } \\
\text { duration }\end{array}$ & Cellular effects & Reference \\
\hline \multirow[t]{10}{*}{$\begin{array}{l}\text { Innate } \\
\text { immunity }\end{array}$} & \multirow[t]{5}{*}{ Macrophages } & $\begin{array}{l}\text { Male } \\
\text { Japanese } \\
\text { quail }\end{array}$ & $\begin{array}{c}50 \text { ppm; } 100 \\
\text { ppm; } 150 \text { ppm }\end{array}$ & 4 weeks & $\begin{array}{l}\text { Cytokine expression (IL-1 } \beta, \mathrm{IL}-6 \text {, and TNF- } \alpha \text { ) and phagocytosis activity was } \\
\text { reduced }\end{array}$ & $(72)$ \\
\hline & & $\begin{array}{l}\text { WT } \\
\text { C57BL6 } \\
\text { mice }\end{array}$ & $100 \mathrm{ng} / \mathrm{kg}$ & $7 \mathrm{~d}$ & $\begin{array}{l}\text { Cd mediates the persistence of classically activated lung macrophages to } \\
\text { exacerbate lung injury }\end{array}$ & $(61)$ \\
\hline & & $\begin{array}{l}\text { Channa } \\
\text { punctatus } \\
\text { Bloch }\end{array}$ & $1.96 \mathrm{mg} / \mathrm{L}$ & $7 d$ & $\begin{array}{l}\text { Cd-induced oxystress triggers apoptosis via both mitochondrial and death receptor } \\
\text { pathways }\end{array}$ & $(73)$ \\
\hline & & $\begin{array}{l}\text { Channa } \\
\text { punctatus } \\
\text { Bloch }\end{array}$ & $1.96 \mathrm{mg} / \mathrm{L}$ & $7 d$ & $\begin{array}{l}\text { The decreased phagocytosis, intracellular killing, and cell adhesion were } \\
\text { significantly reduced }\end{array}$ & $(74)$ \\
\hline & & $\begin{array}{l}\text { Male Balb/c } \\
\text { mice }\end{array}$ & 15 ppm & 2 months & $\begin{array}{l}\text { Cd exposure altered the redox balance, leading to excessive production of reactive } \\
\text { oxygen species that overwhelmed the antioxidant defenses }\end{array}$ & $(43)$ \\
\hline & Neutrophils & $\begin{array}{l}\text { Male Dark } \\
\text { Agouti rats }\end{array}$ & 5 ppm;50 ppm & 1 month & Cd promotes neutrophil proliferation & $(75)$ \\
\hline & \multirow[t]{3}{*}{$\begin{array}{l}\text { Natural killer } \\
\text { (NK) cells }\end{array}$} & $\begin{array}{l}\text { Male Dark } \\
\text { Agouti rats }\end{array}$ & 5 ppm;50 ppm & 1 month & The number of NK cells in the spleens of rats decreased & $(75)$ \\
\hline & & $\begin{array}{l}\text { male } \\
\text { C57BL/6 } \\
\text { mice }\end{array}$ & 50 ppm & 3 weeks & Cd-treated mice had significantly lower Nk cell activity & $(76)$ \\
\hline & & $\begin{array}{l}\text { Wistar } \\
\text { female rats }\end{array}$ & $\begin{array}{l}200 \text { ppm; } 400 \\
\text { ppm }\end{array}$ & $170 \mathrm{~d}$ & $\begin{array}{l}\text { Cd induces both inhibitory and stimulatory effects on rat NK cell number and } \\
\text { cytotoxic activity }\end{array}$ & $(77)$ \\
\hline & $\begin{array}{l}\text { Dendritic } \\
\text { cells (DCs) }\end{array}$ & $\begin{array}{l}\text { Male Swiss } \\
\text { Albino mice }\end{array}$ & $\begin{array}{c}2.5 \mathrm{mg} / \mathrm{kg} ; 5 \\
\mathrm{mg} / \mathrm{kg} ; \\
7.5 \mathrm{mg} / \mathrm{kg} ; 10 \\
\mathrm{mg} / \mathrm{kg} ; 15 \mathrm{mg} / \\
\mathrm{kg}\end{array}$ & 4 weeks & Cd affects DCs maturation and function & (6) \\
\hline \multirow[t]{7}{*}{$\begin{array}{l}\text { Adaptive } \\
\text { immunity }\end{array}$} & \multirow[t]{4}{*}{$\begin{array}{l}\text { T-lymphocyte } \\
\text { (T-cells) }\end{array}$} & $\begin{array}{l}\mathrm{C} 57 \mathrm{Bl} / 6 \\
\text { mice }\end{array}$ & 10 ppm & 7 weeks & $\mathrm{CD}^{+}{ }^{+} \mathrm{CD} 223^{+} \mathrm{T}$-cells were markedly decreased & $(35)$ \\
\hline & & $\begin{array}{l}\text { Male } \\
\text { Sprague } \\
\text { Dawley rats }\end{array}$ & 35 ppm & 10 weeks & $\begin{array}{l}\text { Cadmium exposure also significantly increased the production of } \mathrm{IFN}-\gamma \text {, and IL-10, } \\
\text { and may } \\
\text { affect multiple T cell subsets. }\end{array}$ & $(78)$ \\
\hline & & $\begin{array}{l}\text { Male } \\
\text { Sprague- } \\
\text { Dawley rats }\end{array}$ & $\begin{array}{c}5 \text { ppm; } 10 \\
\text { ppm; } \\
25 \text { ppm; } 50 \\
\text { ppm; } \\
100 \text { ppm }\end{array}$ & 1 month & Cd can cause changes in $\mathrm{CD}^{+}$and $\mathrm{CD}^{+}$cells numbers & $(25)$ \\
\hline & & $\begin{array}{l}\text { Male Dark } \\
\text { Agouti rats }\end{array}$ & $1 \mathrm{mg} \mathrm{Cd} / \mathrm{kg}$ & $30 \mathrm{~d}$ & $\begin{array}{l}\text { Differential effects on proinflammatory T-cell derived cytokines were observed } \\
\text { (decreases of IFN- } \gamma \text { gene expression and ConA-stimulated production }\end{array}$ & $(75)$ \\
\hline & \multirow[t]{3}{*}{$\begin{array}{l}\text { B- } \\
\text { lymphocyte } \\
\text { (B-cells) }\end{array}$} & $\begin{array}{l}\text { Male } \\
\text { Sprague- } \\
\text { Dawley rats }\end{array}$ & $\begin{array}{c}5 \text { ppm; } 10 \\
\text { ppm; } \\
25 \text { ppm; } 50 \\
\text { ppm; } \\
100 \text { ppm }\end{array}$ & 1 month & $\begin{array}{l}\text { Low concentrations of } \mathrm{Cd}(5 \mathrm{ppm} \text { and } 10 \mathrm{ppm}) \text { reduced the number of B-cells, } \\
\text { while high concentrations of } \mathrm{Cd}(25 \mathrm{ppm}, 50 \mathrm{ppm} \text {, and } 100 \mathrm{ppm}) \text { increased the } \\
\text { number of B-cells }\end{array}$ & $(25)$ \\
\hline & & $\begin{array}{l}\text { Male ICR } \\
\text { mice }\end{array}$ & $\begin{array}{l}0.5 \mathrm{mg} \mathrm{Cd} / \mathrm{kg} \\
1 \mathrm{mg} \mathrm{Cd} / \mathrm{kg}\end{array}$ & $5 d$ & $\begin{array}{l}\text { The decrease of blood B lymphocytes is accompanied by the increase in the } \\
\text { number of splenic B lymphocytes }\end{array}$ & $(79)$ \\
\hline & & $\begin{array}{l}\text { Female } \\
\text { mice }\end{array}$ & $\begin{array}{l}5 \mu \mathrm{g} / \mathrm{mL} ; 10 \\
\mu \mathrm{g} / \mathrm{mL} ; 50 \mu \mathrm{g} / \\
\quad \mathrm{mL}\end{array}$ & 4 weeks & Dose-dependent enhancement of B lymphocyte activity and Cd concentration & (28) \\
\hline
\end{tabular}

increasing the toxic effect of Cd on osteoblasts (21). Inflammatory diseases induce oxidative stress through enhanced free radical production in the body, which often results in increased oxidative damage. In immune organs, oxidative stress inhibits immune function $(47,86)$. Cd has been shown to induce oxidative stress and trigger adaptive cellular responses in mammalian cells (63). Therefore, oxidative stress is a potential mechanism by which heavy metals cause immune system disorders. Cd-induced oxidative stress may suppress the inflammatory response of macrophages;
Cd exposure $(0.3,1$, and $3 \mathrm{mM})$ induced oxidative stress and reduced the inflammatory response of mouse macrophages in vitro (42). This suggests that $\mathrm{Cd}$ exposure can inhibit the immune and oxidation systems. Similar findings in vivo have been reported by Ramirez et al.; in mice, long-term exposure to $\mathrm{Cd}(15 \mathrm{ppm})$ altered the reduction-oxidation balance in mouse peritoneal macrophages, leading to excessive ROS production (43). Numerous studies have demonstrated that oxidative stress plays an important role in the physiological regulation of macrophages in Cd-exposed mice $(61,72,74)$. 


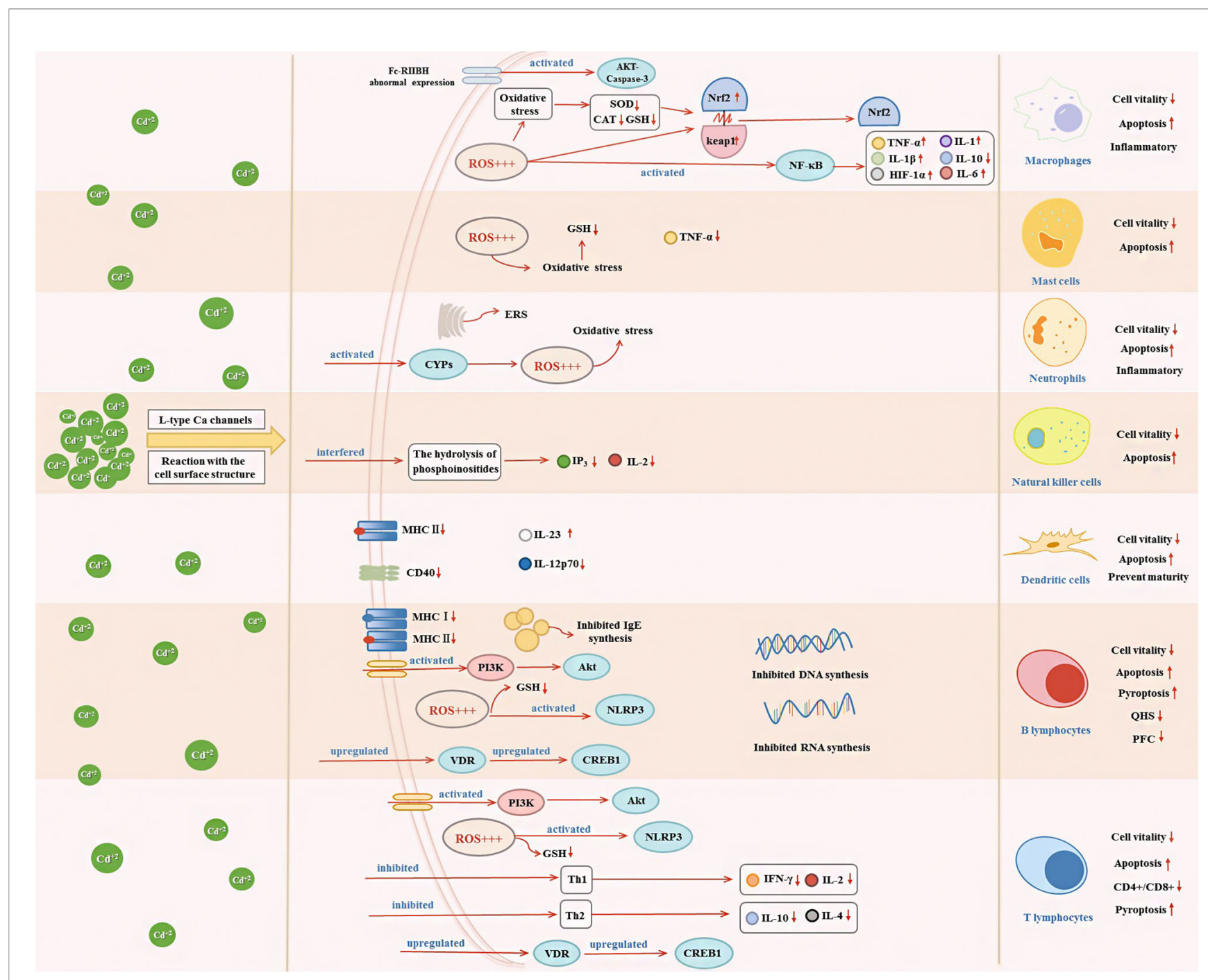

FIGURE 2 | Effects of Cd exposure on innate immune and adaptive immune cells and their underlying mechanisms. Cd ions can enter cells through Ca channels of the L-type or react with surface structures of the cell. After entering the cell, Cd will affect the secretion of immune cytokines through activating oxidative stress, ERS, NF-אB, VDR/CREB, NLRP3, CYPs, and PI3K/Akt signaling pathway, which in turn decrease cell vitality and induce apoptosis.

\section{Cd and M2 Macrophages}

M2 macrophages are classified into three subpopulations, M2a, $\mathrm{M} 2 \mathrm{~b}$, and M2c, all of which are primarily involved in tissue repair and respond to different stimuli (83). The secretion of antiinflammatory factors, such as IL- 4 and IL-10, is considered a hallmark of M2 polarization (87). M2 macrophages play an important role in the regulation of inflammation at infection and tissue damage sites by inhibiting inflammatory responses and regulating tissue repair processes and angiogenesis. Riemschneider et al. found that IL-10 expression was inhibited in macrophages from mice exposed to subtoxic doses of $\mathrm{Cd}$ $(10 \mu \mathrm{M})(64)$.

Fatty acids play various roles in immune cells. Macrophage behavior and the inflammatory state are influenced by fluctuations of fatty acid levels (88). Arachidonic acid is a longchain saturated fatty acid with anti-inflammatory activity found in phospholipids of mouse peritoneal macrophages. Free arachidonic acid is involved in degranulation, phagocytosis, adhesion, and cell proliferation. In mice, $\mathrm{Cd}(10 \mathrm{mM})$ exposure promoted the release of ROS in macrophages and the uptake of arachidonic acid, which may inhibit the M2 polarization of macrophages and reduce the anti-inflammatory activity of macrophages $(63,89)$.

\section{Cd and Mast Cells}

In mammals, the innate immune system is responsible for controlling and limiting the progression of early infections. Mast cells are distributed throughout the body, generally participate in humoral and antibody-mediated immune responses, and play an important role in the first line of immunity (90). Cd toxicity modes, such as oxidative stress, 
depletion of antioxidants, and induction of apoptosis, have different outcomes, depending on the sensitivity of each cell type to different mechanisms (65). García-Mendoza et al. reported that under $\mathrm{Cd}$ exposure in vitro, mouse mast cells showed full dose-response depletion of glutathione (GSH) to below cytotoxic levels. In contrast, LPS-induced TNF- $\alpha$ and immunoglobulin (Ig)E-mediated histamine release in mast cells were attenuated by Cd (65) (Figure 2). Therefore, under Cd exposure, mast cells are more sensitive to oxidative stress.

\section{Cd and Neutrophils}

Another major component of innate immunity is barrier defense, which involves epithelial and endothelial cells. In general, the innate immune system does not discriminate between harmful memory signals. Therefore, inflammation in Cd-containing cells reoccurs repeatedly, changing the recurrence cycle and exacerbating $\mathrm{Cd}$ toxicity over time. This occurs through the activation or inhibition of signaling pathways that alter the expression of anti- and pro-inflammatory mediators (2).

Neutrophils are important participants in the early response to pathogens and acute inflammation. Given the involvement in response to various invading pathogens and the regulation of innate and adaptive immune processes, the malfunction of neutrophils may play an important role in the pathogenesis of many diseases (91). Acute Cd (5 ppm and $50 \mathrm{ppm}$ ) treatment exerted an inflammatory effect in rats and increased the number of neutrophils in their spleens (75). Jiaxin et al. reported that Cd (10 $\mu \mathrm{M}$ ) triggered the cytochrome P450s (CYPs) pathway and impaired antioxidant activity, leading to apoptosis and immunosuppression of neutrophils, in the common carp (44) (Figure 2). Cd-induced neutrophil apoptosis occurs via not only the mitochondriadependent pathway but also ERS pathway (92). An in-vivo study by Chen et al. showed that $\mathrm{Cd}(1 \mu \mathrm{M})$ induced immunosuppressive and inflammatory reactions in chicken neutrophils and triggered apoptosis via the ERS pathway (41) (Figure 2).

\section{Cd and NK Cells}

NK cells are lymphocytes of the innate immune system that play key roles in early antiviral responses, the secretion of cytokines, and the destruction of virus-infected cells (93). Cd targets NK cells in rats. Demenesku et al. found that the number of NK cells in the spleens of rats decreased after acute $\mathrm{Cd}(5 \mathrm{ppm}$ and 50 ppm) treatment. And Chowdhury et al. showed that Cd (50 ppm) exposure reduced the activity of NK cells $(75,76)$. In rats, $\mathrm{Cd}(100 \mu \mathrm{M} ; 200 \mathrm{ppm}$ and $400 \mathrm{ppm})$ ingestion suppressed the number of NK cells and exerted time-dependent toxic effects on NK cells $(66,77)$. In addition, phosphoinositide turnover as a signaling pathway in the activation of NK cells by NK-sensitive tumor target cells. Cd exposure can interfere with the hydrolysis of phosphoinositides, such as the decrease of inositol 1,4,5trisphosphate $\left(\mathrm{IP}_{3}\right)(66)$. Cd exposure also reduced IL-2 cytokine expression (66) (Figure 2). These reports indicate that $\mathrm{Cd}$ has a toxic effect on NK cells.

\section{Cd and DCs}

DCs are antigen-presenting cells that bridge the innate and adaptive immune systems (6). They have efficient cellular uptake processes because immature DCs are located in peripheral tissues and continuously monitor the environment through the uptake of particulate and soluble products. Antigenloaded DCs acquire a mature phenotype, which is associated with reduced endocytic and phagocytic capacities and enhanced production of inflammatory cytokines and chemokines. Mature DCs migrate to the lymphatic organs where they interact with and activate naïve T-cells $(94,95)$. Thus, DCs play a pivotal role in immune homeostasis and act as the primary regulator of immune system processes, including the induction of tolerance and prevention of autoimmunity $(96,97)$.

The ingestion of functional Cd-containing quantum dots results in minor cytotoxicity and inhibition of DC maturation. Chakraborty et al. reported that chronic $\mathrm{CdCl}_{2}(2.5-15 \mathrm{mg} / \mathrm{kg}$ body weight) exposure reduced the expression of key surface molecules, such as major histocompatibility complex (MHC) class II molecules and CD40, in bone-marrow-derived DCs of mice $(6,95)$ (Figure 2). CD40 induces DC maturation, and the decrease in CD40 expression indicated impaired DC maturation. In addition, the release of IL-12 by LPS-activated (IL-12p70) from bone-marrow-derived DCs was reduced, while IL-23 was increased upon $\mathrm{CdCl}_{2}$ exposure (6) (Figure 2). Therefore, Cd acts as an immunosuppressant by hindering DC maturation.

\section{REGULATORY EFFECTS OF CD ON ADAPTIVE IMMUNITY}

\section{Cd and T-Cells}

T-cells are basic immune system cells that play a vital role in the cell-mediated adaptive immune response (90). The thymus is the site of T-cell differentiation and maturation. Considering that $\mathrm{Cd}$ causes DNA damage and that DNA repair by non-homologous end-joining is required for T-lymphocyte differentiation, it could be expected that $\mathrm{Cd}$ affects T-lymphocyte differentiation through this mechanism. However, Viau et al. showed that $\mathrm{Cd}$ does not affect non-homologous end-joining or base and nucleotide repair, but that $\mathrm{Cd}$ toxicity in $\mathrm{T}$-cells is linked to cell-cycle perturbations (98). Cd intake by thymocytes altered the expression of thymocyte surface markers in mice, leading to phenotypic changes, and the lowest Cd concentration used in the study $(10 \mathrm{mM})$ induced changes in different T-cell subsets. In mice, $\mathrm{Cd}$ treatment resulted in dose- and time-dependent accumulations of $\mathrm{Cd}$ in $\mathrm{CD}^{+}$cells and dose- and timedependent decreases in the $\mathrm{CD} 4^{+} / \mathrm{CD}^{+}$ratio, which is a bioindicator of immunotoxicity (36). This immunosuppression is likely to result from reduced expression of IL-2 and interferon (IFN)- $\gamma$ in T-helper (Th) 1 cells and reduced expression of IL-4 in Th2 cells (36). In addition, Cd treatment causes abnormal immune phenotypes in the mouse uterus. Prenatal $\mathrm{Cd}$ exposure affected the transcriptomes of T-cells and $\mathrm{CD} 4{ }^{+}$cells and disrupted cAMP-responsive element-binding protein 1 (CREB1) signaling, which is involved in T-cell stability (99) (Figure 2). When Cd stimulates T-cell subsets, T lymphocytes secrete cytokines, which further regulate the cellular immune response. Additionally, IFN- $\gamma$, TNF- $\alpha$, and IL- 2 secreted by Th1 
lymphocytes inhibit the proliferation of Th2 lymphocytes, while IL-4, IL-5, IL-6, and IL-10 are secreted by Th2 lymphocytes inhibit the proliferation of Th1 lymphocytes. Cd exposure decreased cytokine production in Th1 (e.g., IFN- $\gamma$ and IL-2) and Th2 (e.g., IL-4) lymphocytes $(35,100,101)$ (Figure 2). Cd (35 ppm) affected multiple T-lymphocyte subsets and promoted the expression of inflammatory factors, thereby enhancing the inflammatory response (78). Lafuente et al. analyzed the dosedependent effects of $\mathrm{Cd}$ on blood lymphocyte subsets and found that $\mathrm{CD}^{+}$and $\mathrm{CD} 8^{+}$cell counts decreased at doses of 5 and 10 ppm but increased at a dose of 25 ppm (25) (Figure 2).

Cd exposure at a dose of $1 \mathrm{mg} / \mathrm{kg}$ stimulated innate immune responses in rats; however, respiratory-burst stimuli inhibited $\mathrm{T}$-cell responses (75). In addition, for proliferation, T-cells require zinc $(\mathrm{Zn})$, which has chemical properties similar to those of $\mathrm{Cd}$. Therefore, under $\mathrm{Cd}$ exposure, $\mathrm{Zn}$ intake by $\mathrm{T}$ cells can be inhibited, resulting in the suppression of T-cell proliferation (67). This phenomenon had been reported before $(102,103)$. The regulatory effects of Cd on humoral immunity depend on the activation of cells. Cd polarizes the immune response toward type 2 in cells stimulated via T-cell receptors. Exposure of activated T-cells to low doses of $\mathrm{Cd}$ led to suppression of early Th1 cytokine events and suppression of the Th2 cytokines IL-4 and IL-10 (33) (Figure 2).

\section{Cd and B-Cells}

Heavy metals can affect cells in two ways: by penetrating the interior of the cell through L-type Ca channels and by reacting with the surface structures of the cell (1). Cd affects B lymphocytes through both these ways (1). B-cell activity results in changes in protein expression on the surfaces of specific cells. In female mice, $\mathrm{CdCl}_{2}$ exposure affects the expression of surface antigens in B cells; for example, it inhibits the expression of class I MHC antigen and class II MHC antigens and inhibits the synthesis of B-cell RNA and DNA (69) (Figure 2).

B lymphocytes differentiate and mature in the spleen. Humoral immunity is an immune mechanism through which B lymphocytes are stimulated to produce antibodies that act as effectors of the humoral immune response for protection (104). When humoral immunity is inhibited, antibody-producing B lymphocytes are also inhibited. Cd induction significantly reduced humoral immunity parameters as well as plaqueforming cells and quantitative hemolysis of sheep red blood cell responses, resulting in humoral immunity suppression (104). In addition, $\mathrm{Cd}$ alters the signaling of $\mathrm{B}$ lymphocytes by stimulating the secretion of specific antibodies. When cells are stimulated to produce specific reactions, they respond to the synthesis of different proteins (1). Marth et al. used blood samples from nine healthy adult human donors to show that $\mathrm{Cd}(5,25$, and $50 \mu \mathrm{M})$ induced the transformation of the $\operatorname{IgE}$ antibody, produced by B lymphocytes, into IgG (1). In healthy nonallergic volunteers, $\mathrm{Cd}(0.1,1,2,5$, and $10 \mu \mathrm{M})$ significantly inhibited B-lymphocyte activity in a concentration-dependent manner and selectively inhibited IgE synthesis (70). These data show that the mechanism of action of $\mathrm{Cd}$ in activated $\mathrm{B}$ lymphocytes involves pathways that interrupt the effective initiation of cell activation and transduce a cytotoxic signal.
Numerous in-vitro studies have shown that $\mathrm{Cd}$ can induce apoptosis in various cell types (29). For example, $\mathrm{CdCl}_{2}$ at doses of 5 and $10 \mathrm{ppm}$ induced apoptosis in peripheral blood $\mathrm{B}$ lymphocytes, and $\mathrm{Cd}$ at $5-100 \mu \mathrm{M}$ induced apoptosis in Raji B cells in a dose-dependent manner $(25,30)$. Subcutaneous injections of $\mathrm{Cd}(0.5$ and $1.0 \mathrm{mg} / \mathrm{kg})$ in mice led to a significant reduction in blood B lymphocyte numbers (79). Cd is immunotoxic to B lymphocytes, and $\mathrm{Cd}(0.1-5 \mu \mathrm{M})$ exposure induced autophagy in B lymphocytes, thereby promoting apoptosis of immune cells (71). Cd (40 $\mu \mathrm{M})$ exposure promoted apoptosis by activating inflammasome NOD-like receptor protein 3 (NLRP3) and promoted pyroptosis in splenic lymphocytes of carp fish (105). Cd caused apoptosis of porcine splenocytes through oxidative stress and activated the vitamin D receptor (VDR)/CREB1 pathway (106). Thus, these immunological alterations, activity changes, and apoptosis induction in $\mathrm{T}$ and $\mathrm{B}$ lymphocytes may be related to oxidative stress levels (e.g., they are correlated with GSH content). Ullah et al. reported that $\mathrm{Cd}(0.003-66.66 \mu \mathrm{M})$ exposure destroyed the antioxidant defense system and depleted GSH in T and B lymphocytes to a harmful extent (68). Cd $\left(3.5 \times 10^{-5} \mathrm{M}\right)$ exposure promoted an imbalance of the antioxidant status and activated the phosphoinositide 3-kinase (PI3K)/Akt pathway, along with a decrease in GSH levels, eventually leading to T- and B-lymphocyte apoptosis $(99,107)$ (Figure 2).

\section{POTENTIAL WAYS TO ALLEVIATE CD CYTOTOXICITY}

Cd toxicity is not limited to occupationally exposed workers but also causes moderate to severe health problems in individuals exposed to non-occupational sources of Cd. When Cd enters the human body, it is rapidly transported to various organs via blood circulation. Furthermore, the half-life of Cd in the human body is estimated to be in decades. Cd exposure at concentrations in the micromolar range can lead to significant toxic effects (6). Immune cells develop from hematopoietic stem cells in the bone marrow. In mice, $\mathrm{Cd}(10 \mathrm{ppm})$ interacted directly with hematopoietic stem cells, impairing their function via the activation of noncanonical Wnt signaling, which in turn affects immune function (108). Cd (30, 100, and $300 \mathrm{ppm})$ exerted significant immunosuppressive effects on humoral and cellmediated immune responses in mice (109). Further, acute cadmium exposure can induce inflammatory diseases. For example, in rheumatoid arthritis, acute Cd exposure leads to a significant reduction in the T-to-B-cell ratio, which may produce immune-sensitizing effects (110).

(1) Prevent or mitigate the outcomes of Cd immunotoxicity

The scientific community has been searching for ways to reduce $\mathrm{Cd}$ toxicity. Many of the toxic effects of $\mathrm{Cd}$ are determined by its physical and chemical properties, and trace elements with chemical properties similar to those of $\mathrm{Cd}$ can interact with $\mathrm{Cd}$. Such interactions can occur at different stages of trace element absorption, distribution, and excretion, affecting their biological function (17). The physical and chemical 
similarity between $\mathrm{Cd}$ and $\mathrm{Zn}$ suggests the existence of competitive antagonism. Zn plays key roles in gene expression and cell division and growth via various pathways and is essential for the proper functioning of many enzymes (111). $\mathrm{Zn}$ supplementation can reduce Cd damage to cell morphology and improve the activity of immune cells, such as macrophages and NK cells $(76,112)$. Jemai et al. showed that Cd exposure significantly reduced superoxide dismutase (SOD), and catalase (CAT) activities, triggering oxidative stress reactions, in rats. However, Zn supplementation significantly reduced the concentration of lipid peroxides and inhibited the increase in oxidative stress levels induced by Cd (17). Wang et al. have shown that hydrogen sulfide $\left(\mathrm{H}_{2} \mathrm{~S}\right)$ antagonizes $\mathrm{Cd}^{2+}$ by regulating the antioxidant system, alleviating cell membrane damage, and maintaining intracellular homeostasis (113). In addition, $\mathrm{H}_{2} \mathrm{~S}$ can also reduce inflammatory cell responses by inhibiting NF- $\mathrm{\kappa B}$ pathway activation (114).

Similarly, selenium (Se) supplementation can promote the proliferation of immune cells, such as T-cells and NK cells (115, 116). Se has antioxidant properties and regulates immunity by functioning as a trace element $(117,118)$. Ge et al. have shown that Se nanoparticles weakened $\mathrm{Cd}$-induced inflammatory responses through the NF- $\mathrm{BB}$ pathway (119). Se antagonizes Cd-induced toxicity via ROS-dependent oxidative stress and protects lymphocytes from Cd-induced apoptosis by inhibiting the PI3K/Akt pathway (120). Se antagonized ERS induced by Cd and effectively protected chicken neutrophils from changes caused by Cd (41). Metal elements and their organic compounds have dynamic regulation in cells (111). Iron (Fe) regulates the immune response in immune cells such as macrophages $(121,122)$. Chemical elements used for intervention may act antagonistically with $\mathrm{Cd}$, improving Cdinduced immune damage. Metal ions (e.g., sodium (Na), Fe, and aluminum $(\mathrm{Al})$ ) can be combined with biosorption materials to improve their adsorption performance, and such materials can be used to remove Cd $(123,124)$.

(2) Block the activation of Cd-induced signaling pathways

Some of the ways to antagonize Cd toxicity are inhibiting ROS generation, reducing oxidative stress levels, maintaining redox balance, and inhibiting abnormal immune signaling activation. Bioactive compounds such as vitamins $\mathrm{A}$ and $\mathrm{C}$, phenolic compounds, and flavonoids have good antioxidant activities or can improve antioxidant enzyme activity and thus reduce oxidative stress levels and inhibit signaling activation (125). Hyperoside inhibits LPS-induced inflammatory responses in microglial cells via the NF- $\mathrm{BB}$ pathway. Wild simulated ginseng activates RAW264.7 mouse macrophages through TRL2/4-dependent activation of the MAPK, NF- $\kappa B$, and PI3K/ Akt pathways. And vitamin $\mathrm{C}$ enhances the antioxidant ability of chicken myocardium cells to relieve heat stress injury (126-128). In addition, Cd exposure affects the composition of lymphocyte subsets and induces apoptosis of CD4 and CD8 cells. Fawzi et al. showed that multivitamins induced significant increases in CD4, CD8, and CD3 cell counts (129). Thus, in addition to trace elements, intervention with natural active ingredients or vitamins may inhibit the immunotoxicity of $\mathrm{Cd}$.
Abnormal cytokine secretion and gene expression can affect normal cellular immune signaling activation. Cd affects cytokine expression and secretion by altering the activity of immune cells. For example, it promotes the expression of the pro-inflammatory factors IL-1 $\beta$, IL- 6 , and TNF- $\alpha$ in macrophages by increasing ROS production, while inhibiting that of the anti-inflammatory cytokine IL-10 $(46,74)$. Therefore, blocking NF- $\kappa B$ signaling, oxidative stress, and the expression of pro-inflammatory factors, and promoting anti-inflammatory factors may be useful to alleviate $\mathrm{Cd}$ immunotoxicity. Catechin hydrate reduces $\mathrm{Cd}$ related genotoxicity and cytotoxicity by inhibiting related apoptotic gene expression (130). Resveratrol protects cells from oxidative stress damage by activating NF- $\mathrm{KB}$ signaling (131). Hyperoside significantly reduces the expression of IL- $1 \beta$ and TNF- $\alpha$ through NF- $\kappa \mathrm{B}$ signaling, thereby suppressing the inflammatory response of cells (127). In addition to naturally active products, some essential trace elements, such as $\mathrm{Zn}$ and Se, and vitamins perform similar biological functions in the body (e.g., anti-inflammatory and antiviral activities) through the NF$\kappa \mathrm{B}$ pathway. Se inhibits NF- $\kappa \mathrm{B}$ pathway activation and reduces oxidative stress levels and promotes the expression of the antiinflammatory cytokine IL-2 (132-134). Vitamins C, D, and E all regulate NF- $\mathrm{KB}$ signaling and have biological activity (135-137). The toxic effects of $\mathrm{Cd}$ on the spleen and B lymphocytes can be effectively reduced by inhibiting autophagy NLRP3 activity and by suppressing lymphocyte pyroptosis $(71,105)$.

Based on a better understanding of the pathways of Cdinduced immunotoxicity, interventions using inhibitors (e.g., metal ions, vitamins, and natural active products) can be designed and developed to effectively reduce Cd toxicity. While studying the immunosuppressive and toxic effects of $\mathrm{Cd}$ in the body, it is necessary to find effective measures to disrupt the activation of the mechanisms of Cd toxicity. Accordingly, reducing $\mathrm{Cd}$ accumulation in human organs and cells, alleviating its toxic effects, and reducing the risk of $\mathrm{Cd}$ associated disease will be important research objectives in the future (Table 3) $(41,46,84,85,105,120)$.

\section{SUMMARY AND PERSPECTIVES}

Cd enters the body through inhalation and ingestion. It accumulates in different various organs, tissues, and cells, and acts on immune organs and immune cells. Thus far to date, most studies investigating the effects of $\mathrm{Cd}$ exposure on immunomodulation have been committed to exploring the effects of focused on Cd toxicity ion the different organs, while; the changes that induced by $\mathrm{Cd}$ in immune cells undergo following $\mathrm{Cd}$ exposure, as well as its toxicity mechanisms and corresponding potential detoxification mechanisms, are less extensively studied.

When in immune cells, Cd dose-dependently affects cell vitality and functions and can induce apoptosis. Cd exposure impacts innate immunity in terms of phagocytic capacity, proliferation, and status transformation of macrophages, reduction of the number of NK cells, and the increase of 
TABLE 3 | The detoxification mechanism to inhibit Cd immunotoxicity.

\begin{tabular}{|c|c|c|c|}
\hline Cd and cells & Toxic effects on cells & Detoxification mechanism & Referenc \\
\hline \multirow[t]{4}{*}{ Macrophages } & $\begin{array}{l}\text { Cd promotes macrophage TNF- } \alpha, \mathrm{IL}-6, \mathrm{IL}-1, \mathrm{NO} \text {, and } \\
\text { catalase activity }\end{array}$ & $\begin{array}{l}\text { Glycine reduces Cd-induced alterations in the viability and activation of } \\
\text { macrophages }\end{array}$ & $(84)$ \\
\hline & Cd accumulated in macrophages and produces toxicity & $\begin{array}{l}\text { Metallothionein intervention can be combined with Cd to inhibit Cd-induced } \\
\text { toxicity }\end{array}$ & $(85)$ \\
\hline & $\begin{array}{l}\text { Cd inhibits the phagocytotic activity of chicken peritoneal } \\
\text { macrophages }\end{array}$ & Antagonistic effect of $\mathrm{N}$-acetyl-L-cysteine against Cd-induced Cytotoxicity & $(46)$ \\
\hline & $\begin{array}{l}\text { Cd caused dose-dependent morphologic and ultrastructural } \\
\text { alterations in macrophages }\end{array}$ & Zn against $\mathrm{Cd}$ cytotoxicity in macrophages & $(112)$ \\
\hline Neutrophiles & Cd caused apoptosis by endoplasmic reticulum stress & $\begin{array}{l}\text { Se can be antagonists with cd, effectively protecting chicken neutrophils from } \\
\text { changes caused by Cd. }\end{array}$ & $(41)$ \\
\hline $\begin{array}{l}\text { Natural killer } \\
(\mathrm{NK}) \text { cells }\end{array}$ & Cd can reduce the activity of NK cells & Zn can significantly increase the activity of NK cells & $(76)$ \\
\hline \multirow[t]{5}{*}{ Lymphocytes } & Cd caused apoptosis of exodus lymphocytes & Sulforaphane therapy restores Cd-induced apoptosis by $17 \%$ to $20 \%$ & $(138)$ \\
\hline & $\begin{array}{l}\text { Cd caused autophagy and promoted apoptosis of B } \\
\text { lymphocytes }\end{array}$ & Inhibit autophagy & $(71)$ \\
\hline & Cd promoted lymphocytes pyroptosis & Inhibitory NLRP3 activity & $(105)$ \\
\hline & $\begin{array}{l}\text { Cd promoted apoptosis and necrosis of carp lymphocytes } \\
\text { by regulating the miR-216a-PI3K/AKT axis }\end{array}$ & $\begin{array}{l}\text { Se antagonizes Cd toxicity through ROS-dependent oxidative stress and } \\
\text { PI3K/AKT pathways. }\end{array}$ & $(120)$ \\
\hline & Cd has cytotoxicity and genotoxicity to human lymphocytes & $\begin{array}{l}\text { Catechin hydrate can inhibit the anti-genotoxicity and anti-cytotoxicity of } \mathrm{Cd} \\
\text { by inhibiting the expression of related apoptotic genes }\end{array}$ & $(130)$ \\
\hline
\end{tabular}

neutrophils, thus resulting in an inflammatory response. Cd exposure affects adaptive immunity mainly by resulting in apoptosis of T-cells and B-cells. In B-cells, Cd exposure affects surface antigen expression and selectively inhibits the synthesis of antibodies. Thus, Cd exposure can directly affect the growth of immune cells and their function.

As immune cells grow, they become polarized, producing different cell phenotypes. Lymphocyte subset composition is closely related to the immune capacity of the immune system. Different lymphocyte subsets exhibit different sensitivities to $\mathrm{Cd}$ exposure. T subsets respond to the apoptogenic effects of $\mathrm{Cd}$ in the order $\mathrm{CD}^{+}>\mathrm{CD}^{-} \mathrm{CD} 8^{-}>\mathrm{CD} 4^{+} \mathrm{CD} 8^{+}>\mathrm{CD}^{+}$(36). The $\mathrm{CD} 4^{+} / \mathrm{CD}^{+}$ratio changes proportionally to $\mathrm{Cd}$ concentration and exposure time. In addition, $\mathrm{Cd}$ exposure leads to a significant increase in the Th17 lymphocyte subset and significant decreases in the Th1 and Th2 lymphocyte subsets (11). Thus, lymphocyte subsets are affected by Cd in concentration- and exposure timedependent manners.

Immune cells secrete certain cytokines upon internal or external stimulus. Cd can affect the secretion and expression of cytokines. For example, in M1 macrophages, Cd reduces IL-1 $\beta$, IL-6, and TNF- $\alpha$ expression; in M2 macrophages, it reduces IL- 6 and IL-10 expression; and in lymphocytes, it reduces IFN- $\gamma$, IL- 2 , and IL-4 production. In addition, $\mathrm{Cd}$ exposure is often closely related to inflammation. For example, $\mathrm{Cd}$ exposure can exert an inflammatory effect by inducing ROS production, reducing antioxidant enzyme activity, and activating oxidative stress and ERS pathways. Through the induction of abnormal cytokine secretion and inflammatory reactions, Cd exposure can also affect normal immune signaling pathways of cells, e.g., by activating the MAPK pathway and NF- $\mathrm{KB}$-dependent gene expression. This affects the proliferation and phenotypic transformation of macrophages, which in turn leads to macrophage immune dysfunction. Activation of the PI3K/Akt pathway promotes redox imbalance and in turn triggers inflammation and lymphocyte apoptosis. Cd has similar chemical properties as $\mathrm{Ca}$ and thus can enter cells through $\mathrm{Ca}^{2+}$ channels to increase intracellular $\mathrm{Ca}$ concentrations. Cd-induced $\mathrm{Ca}^{2+}$ regulates the phosphorylation/ dephosphorylation of c-Jun NH2-terminal kinase and p38 MAPK and modulates macrophage immune activity (139). Cd can interfere with the CREB1 pathway, affecting the distribution and stability of lymphocyte populations. Thus, Cd can affect cytokine secretion by affecting the growth of immune cells and subsequently activate abnormal immune signaling pathways to produce immunotoxic effects and damage the immune function of the body.

Few studies have focused on the toxicity and mechanisms of $\mathrm{Cd}$ in immune cells. Thus, there is an urgent need to unravel the toxic effects and mechanisms of $\mathrm{Cd}$ in immune cells and to develop effective immunotherapies to alleviate the toxic effects of $\mathrm{Cd}$. Based on present data on the signaling and inflammatory pathways induced by $\mathrm{Cd}$ immunotoxicity, regulating cellular immune activities and normal cytokine secretion and reducing the activation of certain signaling pathways may effectively inhibit Cd immunotoxicity. In conclusion, Cd can inhibit innate and adaptive immunity, suppress immune system functions, and lead to the onset of various chronic diseases.

Therefore, for both occupational or non-occupational exposure to $\mathrm{Cd}$, it is important to resume research to improve public health immunization and to reduce the toxic effects of $\mathrm{Cd}$ on the immune system. A continued search for active substances in natural products that inhibit $\mathrm{Cd}$ toxicity will facilitate the discovery of compounds that prevent $\mathrm{Cd}$ accumulation as well as Cd-related immune diseases.

\section{AUTHOR CONTRIBUTIONS}

ZW and YS drafted the manuscript. WY, QB, and HW drafted and revised the manuscript. All authors contributed to the article and approved the submitted version. 


\section{FUNDING}

This study was supported by grants from the National Nature Science Foundation (81630086, 82030099 and 81973078), National Key R\&D Program of China (2018YFC2000700), Shanghai Municipal Human Resources and Social Security Bureau (2018060), Shanghai Public Health System

\section{REFERENCES}

1. Marth E, Jelovcan S, Kleinhappl B, Gutschi A, Baryh S. The Effect of Heavy Metales on the Immune System at Low Concentrations. Int J Occup Med Environ Health (2001) 14(4):375-86.

2. Knoell DL, Wyatt TA. The Adverse Impact of Cadmium on Immune Function and Lung Host Defense. Semin Cell Dev Biol (2021) 115:70-6. doi: 10.1016/j.semcdb.2020.10.007

3. Briffa J, Sinagra E, Blundell R. Heavy Metal Pollution in the Environment and Their Toxicological Effects on Humans. Heliyon (2020) 6(9):e04691. doi: 10.1016/j.heliyon.2020.e04691

4. Khan MA, Khan S, Khan A, Alam M. Soil Contamination With Cadmium, Consequences and Remediation Using Organic Amendments. Sci Total Environ (2017) 601-602:1591-605. doi: 10.1016/j.scitotenv.2017.06.030

5. Hossein-Khannazer N, Azizi G, Eslami S, Alhassan Mohammed H, Fayyaz F, Hosseinzadeh R, et al. The Effects of Cadmium Exposure in the Induction of Inflammation. Immunopharmacol Immunotoxicol (2020) 42(1):1-8. doi: 10.1080/08923973.2019.1697284

6. Chakraborty K, Chatterjee S, Bhattacharyya A. Modulation of Phenotypic and Functional Maturation of Murine Bone-Marrow-Derived Dendritic Cells (BMDCs) Induced by Cadmium Chloride. Int Immunopharmacol (2014) 20(1):131-40. doi: 10.1016/j.intimp.2014.02.015

7. Lener MR, Reszka E, Marciniak W, Lesicka M, Baszuk P, Jabłońska E, et al. Blood Cadmium Levels as a Marker for Early Lung Cancer Detection. J Trace Elem Med Biol (2021) 64:126682. doi: 10.1016/ j.jtemb.2020.126682

8. Tian J, Li Z, Wang L, Qiu D, Zhang X, Xin X, et al. Metabolic Signatures for Safety Assessment of Low-Level Cadmium Exposure on Human OsteoblastLike Cells. Ecotoxicol Environ Saf (2021) 207:111257. doi: 10.1016/ j.ecoenv.2020.111257

9. Kubier A, Wilkin RT, Pichler T. Cadmium in Soils and Groundwater: A Review. Appl Geochem (2019) 108:1-16. doi: 10.1016/j.apgeochem.2019.104388

10. Birgisdottir BE, Knutsen HK, Haugen M, Gjelstad IM, Jenssen MTS, Ellingsen DG, et al. Essential and Toxic Element Concentrations in Blood and Urine and Their Associations With Diet: Results From a Norwegian Population Study Including High-Consumers of Seafood and Game. Sci Total Environ (2013) 463-464:836-44. doi: 10.1016/j.scitotenv.2013.06.078

11. Goyal T, Mitra P, Singh P, Ghosh R, Lingeswaran M, Sharma S, et al. Estimation of Lymphocyte Subsets and Cytokine Levels in Workers Occupationally Exposed to Cadmium. J Trace Elem Med Biol (2021) 64:126681. doi: 10.1016/j.jtemb.2020.126681

12. Cao X, Fu M, Bi R, Zheng X, Fu B, Tian S, et al. Cadmium Induced BEAS-2B Cells Apoptosis and Mitochondria Damage Via MAPK Signaling Pathway. Chemosphere (2021) 263:128346. doi: 10.1016/j.chemosphere.2020.128346

13. Satarug S, Vesey DA, Gobe GC. Current Health Risk Assessment Practice for Dietary Cadmium: Data From Different Countries. Food Chem Toxicol (2017) 106:430-45. doi: 10.1016/j.fct.2017.06.013

14. Xiong R, Wu Q, Trbojevich R, Muskhelishvili L, Davis K, Bryant M, et al. Disease-Related Responses Induced by Cadmium in an In Vitro Human Airway Tissue Model. Toxicol Lett (2019) 303:16-27. doi: 10.1016/ j.toxlet.2018.12.009

15. Wang D, Sun H, Wu Y, Zhou Z, Ding Z, Chen X, et al. Tubular and Glomerular Kidney Effects in the Chinese General Population With Low Environmental Cadmium Exposure. Chemosphere (2016) 147:3-8. doi: 10.1016/j.chemosphere.2015.11.069

16. Ibraheem AS, Seleem AA, El-Sayed MF, Hamad BH. Single or Combined Cadmium and Aluminum Intoxication of Mice Liver and Kidney With
Construction Three-Year Action Plan (GWV-10.1-XK15), the Major Science and Technology Innovation Program of Shanghai Municipal Education Commission (2019-01-07-0001-E00059), the International Cooperation Project of Guangzhou Development Zone (2017GH11), and Innovative Research Team of High-Level Local Universities in Shanghai.

Possible Effect of Zinc. J Basic Appl Zool (2016) 77:91-101. doi: 10.1016/ j.jobaz.2016.12.004

17. Jemai H, Messaoudi I, Chaouch A, Kerkeni A. Protective Effect of Zinc Supplementation on Blood Antioxidant Defense System in Rats Exposed to Cadmium. J Trace Elem Med Biol (2007) 21(4):269-73. doi: 10.1016/ j.jtemb.2007.08.001

18. Zhao Z, Hyun JS, Satsu H, Kakuta S, Shimizu M. Oral Exposure to Cadmium Chloride Triggers an Acute Inflammatory Response in the Intestines of Mice, Initiated by the Over-Expression of Tissue Macrophage Inflammatory Protein-2 mRNA. Toxicol Lett (2006) 164(2):144-54. doi: 10.1016/ j.toxlet.2005.12.004

19. Ninkov M, Popov Aleksandrov A, Demenesku J, Mirkov I, Mileusnic D, Petrovic A, et al. Toxicity of Oral Cadmium Intake: Impact on Gut Immunity. Toxicol Lett (2015) 237(2):89-99. doi: 10.1016/j.toxlet.2015.06.002

20. Ba Q, Li M, Chen P, Huang C, Duan X, Lu L, et al. Sex-Dependent Effects of Cadmium Exposure in Early Life on Gut Microbiota and Fat Accumulation in Mice. Environ Health Perspect (2017) 125(3):437-46. doi: 10.1289/ EHP360

21. Lizotte J, Abed E, Signor C, Malu DT, Cuevas J, Kevorkova O, et al. Expression of Macrophage Migration Inhibitory Factor by Osteoblastic Cells: Protection Against Cadmium Toxicity. Toxicol Lett (2012) 215 (3):167-73. doi: 10.1016/j.toxlet.2012.10.006

22. Reyes-Hinojosa D, Lozada-Pérez CA, Zamudio Cuevas Y, López-Reyes A, Martínez-Nava G, Fernández-Torres J, et al. Toxicity of Cadmium in Musculoskeletal Diseases. Environ Toxicol Pharmacol (2019) 72:103219. doi: 10.1016/j.etap.2019.103219

23. Ou L, Wang H, Wu Z, Wang P, Yang L, Li X, et al. Effects of Cadmium on Osteoblast Cell Line: Exportin 1 Accumulation, p-JNK Activation, DNA Damage and Cell Apoptosis. Ecotoxicol Environ Saf (2021) 208:111668. doi: 10.1016/j.ecoenv.2020.111668

24. Dkhil MA, Diab MSM, Lokman MS, El-Sayed H, Aljawdah HMA, AlQuraishy S, et al. Hepato-Protective Effect of Pleurotus Ostreatus Extracts in Cadmium- Intoxicated Rats. J King Saud Univ Sci (2020) 32(8):3432-6. doi: 10.1016/j.jksus.2020.09.029

25. Lafuente A, González-Carracedo A, Esquifino AI. Differential Effects of Cadmium on Blood Lymphocyte Subsets. BioMetals (2004) 17(4):451-6. doi: 10.1023/b:biom.0000029441.20037.72

26. Ben Mimouna S, Boughammoura S, Chemek M, Haouas Z, Banni M, Messaoudi I. Disruption of the Zinc Metabolism in Rat Fœtal Brain After Prenatal Exposure to Cadmium. Chem Biol Interact (2018) 286:88-95. doi: 10.1016/j.cbi.2018.03.005

27. Yu G, Zheng W, Wang W, Dai F, Zhang Z, Yuan Y, et al. Health Risk Assessment of Chinese Consumers to Cadmium Via Dietary Intake. J Trace Elem Med Biol (2017) 44:137-45. doi: 10.1016/j.jtemb.2017.07.003

28. Blakley BR. The Effect of Cadmium Chloride on the Immune Response in Mice. Can J Comp Med (1985) 49(1):104-8. doi: 10.1016/0007-1935(85)90153-8

29. Pathak N, Khandelwal S. Role of Oxidative Stress and Apoptosis in Cadmium Induced Thymic Atrophy and Splenomegaly in Mice. Toxicol Lett (2007) 169(2):95-108. doi: 10.1016/j.toxlet.2006.12.009

30. Tsangaris GT, Tzortzatou-Stathopoulou F. Cadmium Induces Apoptosis Differentially on Immune System Cell Lines. Toxicology (1998) 128(2):14350. doi: 10.1016/S0300-483X(98)00032-8

31. Boscolo P, Di Giampaolo L, Qiao N, Reale M, Castellani ML, Lucci I, et al. Inhibitory Effects of Cadmium on Peripheral Blood Mononuclear Cell Proliferation and Cytokine Release Are Reversed by Zinc and Selenium Salts. Ann Clin Lab Sci (2005) 35(2):115-20. doi: 10.1097/00007691200504000-00213 
32. Chatterjee S, Kundu S, Bhattacharyya A. Mechanism of Cadmium Induced Apoptosis in the Immunocyte. Toxicol Lett (2008) 177(2):83-9. doi: 10.1016/ j.toxlet.2007.12.010

33. Hemdan NY, Emmrich F, Sack U, Wichmann G, Lehmann J, Adham K, et al. The In Vitro Immune Modulation by Cadmium Depends on the Way of Cell Activation. Toxicology (2006) 222(1-2):37-45. doi: 10.1016/j.tox.2006.01.026

34. Desforges J-PW, Sonne C, Levin M, Siebert U, De Guise S, Dietz R. Immunotoxic Effects of Environmental Pollutants in Marine Mammals. Environ Int (2016) 86:126-39. doi: 10.1016/j.envint.2015.10.007

35. Hanson ML, Holásková I, Elliott M, Brundage KM, Schafer R, Barnett JB. Prenatal Cadmium Exposure Alters Postnatal Immune Cell Development and Function. Toxicol Appl Pharmacol (2012) 261(2):196-203. doi: 10.1016/ j.taap.2012.04.002

36. Pathak N, Khandelwal S. Impact of Cadmium in T Lymphocyte Subsets and Cytokine Expression: Differential Regulation by Oxidative Stress and Apoptosis. Biometals (2008) 21(2):179-87. doi: 10.1007/s10534-007-9106-7

37. Holásková I, Elliott M, Hanson ML, Schafer R, Barnett JB. Prenatal Cadmium Exposure Produces Persistent Changes to Thymus and Spleen Cell Phenotypic Repertoire as Well as the Acquired Immune Response. Toxicol Appl Pharmacol (2012) 265(2):181-9. doi: 10.1016/j.taap. 2012.10.009

38. Misra UK, Gawdi G, Akabani G, Pizzo SV. Cadmium-Induced DNA Synthesis and Cell Proliferation in Macrophages: The Role of Intracellular Calcium and Signal Transduction Mechanisms. Cell Signal (2002) 14 (4):327-40. doi: 10.1016/S0898-6568(01)00268-6

39. Hernandez M, Macia M, Conde JL, de la Fuente M. Cadmium and Nickel Modulation of Adherence Capacity of Murine Peritoneal Macrophages and Lymphocytes. Intersexual Comparisons. Int J Biochem (1991) 23(5):541-4. doi: 10.1016/0020-711X(87)90047-4

40. Olszowski T, Baranowska-Bosiacka I, Gutowska I, Chlubek D. ProInflammatory Properties of Cadmium. Acta Biochim Pol (2012) 59 (4):475-82. doi: 10.18388/abp.2012_2080

41. Chen J, Pan T, Wan N, Sun Z, Zhang Z, Li S. Cadmium-Induced Endoplasmic Reticulum Stress in Chicken Neutrophils Is Alleviated by Selenium. J Inorg Biochem (2017) 170:169-77. doi: 10.1016/ j.jinorgbio.2017.02.022

42. Jin Y, Liu L, Zhang S, He R, Wu Y, Chen G, et al. Cadmium Exposure to Murine Macrophages Decreases Their Inflammatory Responses and Increases Their Oxidative Stress. Chemosphere (2016) 144:168-75. doi: 10.1016/j.chemosphere.2015.08.084

43. Ramirez DC, Gimenez MS. Induction of Redox Changes, Inducible Nitric Oxide Synthase and Cyclooxygenase-2 by Chronic Cadmium Exposure in Mouse Peritoneal Macrophages. Toxicol Lett (2003) 145(2):121-32. doi: 10.1016/S0378-4274(03)00237-6

44. Jiaxin S, Shengchen W, Yirong C, Shuting W, Shu L. Cadmium Exposure Induces Apoptosis, Inflammation and Immunosuppression Through CYPs Activation and Antioxidant Dysfunction in Common Carp Neutrophils. Fish Shellfish Immunol (2020) 99:284-90. doi: 10.1016/j.fsi.2020.02.015

45. Chen M, Li X, Fan R, Cao C, Yao H, Xu S. Selenium Antagonizes CadmiumInduced Apoptosis in Chicken Spleen But Not Involving Nrf2-Regulated Antioxidant Response. Ecotoxicol Environ Saf (2017) 145:503-10. doi: 10.1016/j.ecoenv.2017.08.001

46. Zhang D, Yang X-y, Qin Y-z, Wu G-d, Ning G-b, Huo N-r, et al. Antagonistic Effect of N-Acetyl-L-Cysteine Against Cadmium-Induced Cytotoxicity and Abnormal Immune Response on Chicken Peritoneal Macrophages. Ecotoxicol Environ Saf (2020) 206:111185. doi: 10.1016/ j.ecoenv.2020.111185

47. Pathak N, Khandelwal S. Influence of Cadmium on Murine Thymocytes: Potentiation of Apoptosis and Oxidative Stress. Toxicol Lett (2006) 165 (2):121-32. doi: 10.1016/j.toxlet.2006.02.004

48. Pathak N, Khandelwal S. Oxidative Stress and Apoptotic Changes in Murine Splenocytes Exposed to Cadmium. Toxicology (2006) 220(1):26-36. doi: 10.1016/j.tox.2005.11.027

49. Nicholson LB. The Immune System. Essays Biochem (2016) 60(3):275-301. doi: 10.1042/EBC20160017

50. Farmer JD, Packard NH, Perelson AS. The Immune System, Adaptation, and Machine Learning. Physica (1986) 22(1-3):187-204. doi: 10.1016/0167-2789 (86)90240-x
51. Kumar A, Sharma N, Singh S, Sasmal, Dev A. Oral Vaccine Antigen Induced Immune Response Signalling Pathways: Current and Future Perspectives. J Vaccines Vaccin (2014) 5(3):1-6. doi: 10.4172/2157-7560.1000225

52. Moraes-Pinto MI, Suano-Souza F, Aranda CS. Immune System: Development and Acquisition of Immunological Competence. J Pediatr (Rio J) (2021) 97 Suppl 1:S59-66. doi: 10.1016/j.jped.2020.10.006

53. Dai J, Fang P, Saredy J, Xi H, Ramon C, Yang W, et al. MetabolismAssociated Danger Signal-Induced Immune Response and Reverse Immune Checkpoint-Activated CD40(+) Monocyte Differentiation. J Hematol Oncol (2017) 10(1):141. doi: 10.1186/s13045-017-0504-1

54. Sun L, Wang X, Saredy J, Yuan Z, Yang X, Wang H. Innate-Adaptive Immunity Interplay and Redox Regulation in Immune Response. Redox Biol (2020) 37:101759. doi: 10.1016/j.redox.2020.101759

55. Yasukawa K, Koshiba T. Mitochondrial Reactive Zones in Antiviral Innate Immunity. Biochim Biophys Acta (BBA) - Gen Subj (2021) 1865(3):129839. doi: 10.1016/j.bbagen.2020.129839

56. Watanabe M, Fujihara C, Radtke AJ, Chiang YJ, Bhatia S, Germain RN, et al. Co-Stimulatory Function in Primary Germinal Center Responses: CD40 and B7 Are Required on Distinct Antigen-Presenting Cells. J Exp Med (2017) 214 (9):2795-810. doi: 10.1084/jem.20161955

57. Viana I, Roussel S, Defrêne J, Lima EM, Barabé F, Bertrand N. Innate and Adaptive Immune Responses Toward Nanomedicines. Acta Pharm Sin B (2021) 11(4):852-70. doi: 10.1016/j.apsb.2021.02.022

58. Mirkov I, Aleksandrov AP, Ninkov M, Tucovic D, Kulas J, Zeljkovic M, et al Immunotoxicology of Cadmium: Cells of the Immune System as Targets and Effectors of Cadmium Toxicity. Food Chem Toxicol (2021) 149:112026. doi: 10.1016/j.fct.2021.112026

59. Loose LD, Silkworth JB, Simpson DW. Influence of Cadmium on the Phagocytic and Microbicidal Activity of Murine Peritoneal Macrophages, Pulmonary Alveolar Macrophages, and Polymorphonuclear Neutrophils. Infect Immun (1978) 22(2):378. doi: 10.1128/iai.22.2.378-381.1978

60. Wu G, Jiang C, Zhang T. Fc $\gamma$ RIIB Receptor-Mediated Apoptosis in Macrophages Through Interplay of Cadmium Sulfide Nanomaterials and Protein Corona. Ecotoxicol Environ Saf (2018) 164:140-8. doi: 10.1016/ j.ecoenv.2018.08.025

61. Larson-Casey JL, Gu L, Fiehn O, Carter AB. Cadmium-Mediated Lung Injury Is Exacerbated by the Persistence of Classically Activated Macrophages. J Biol Chem (2020) 295(46):15754-66. doi: 10.1074/ jbc.RA120.013632

62. Cox JN, Rahman MA, Bao S, Liu M, Wheeler SE, Knoell DL. Cadmium Attenuates the Macrophage Response to LPS Through Inhibition of the NFкB Pathway. Am J Physiol Lung Cell Mol Physiol (2016) 311(4):L754-L65 doi: 10.1152/ajplung.00022.2016

63. Ramirez DC, Riera CM, Gimenez MS. Modulation of Arachidonic Acid Turnover in Macrophages by Cadmium. Toxicol Lett (2001) 122(1):9-19. doi: 10.1016/S0378-4274(01)00342-3

64. Riemschneider S, Herzberg M, Lehmann J. Subtoxic Doses of Cadmium Modulate Inflammatory Properties of Murine RAW 264.7 Macrophages. BioMed Res Int (2015) 2015:295303. doi: 10.1155/2015/295303

65. García-Mendoza D, Han B, Berg HJHJ, Brink NW. Cell-Specific ImmuneModulation of Cadmium on Murine Macrophages and Mast Cell Lines In Vitro. J Appl Toxicol (2019) 39(7):992-1001. doi: 10.1002/jat.3788

66. Cifone MG, Procopio A, Napolitano T, Alesse E, Santoni G, Santoni A. Cadmium Inhibits Spontaneous (NK), Antibody-Mediated (ADCC) and IL-2Stimulated Cytotoxic Functions of Natural Killer Cells. Immunopharmacology (1990) 20(2):73-80. doi: 10.1016/0162-3109(90)90009-4

67. Otsuka F, Ohsawa M. Differential Susceptibility of T- and B-Lymphocyte Proliferation to Cadmium: Relevance to Zinc Requirement in T-Lymphocyte Proliferation. Chem Biol Interact (1991) 78(2):193-205. doi: 10.1016/0009 2797(91)90014-X

68. Ullah H, Khan MF, Jan SU, Hashmat F. Cadmium-Glutathione Complex Formation in Human T-Cell and B-Cell Lymphocytes After Their Incubation With Organo-Cadmium Diacetate. Pak J Pharm Sci (2015) 28 (6):2075-81

69. Daum JR, Shepherd DM, Noelle RJ. Immunotoxicology of Cadmium and Mercury on B-Lymphocytes - I. Effects on Lymphocyte Function. Int J Immunopharmacol (1993) 15(3):383-94. doi: 10.1016/0192-0561(93) 90049-5 
70. Jelovcan S, Gutschi A, Kleinhappl B, Sedlmayr P, Barth S, Marth E. Effects of Low Concentrations of Cadmium on Immunoglobulin E Production by Human B Lymphocytes In Vitro. Toxicology (2003) 188(1):35-48. doi: 10.1016/S0300-483X(03)00044-1

71. Gu J, Wang Y, Liu Y, Shi M, Yin L, Hou Y, et al. Inhibition of Autophagy Alleviates Cadmium-Induced Mouse Spleen and Human B Cells Apoptosis. Toxicol Sci (2019) 170(1):109-22. doi: 10.1093/toxsci/kfz089

72. Sant'Ana MG, Moraes R, Bernardi MM. Toxicity of Cadmium in Japanese Quail: Evaluation of Body Weight, Hepatic and Renal Function, and Cellular Immune Response. Environ Res (2005) 99(2):273-7. doi: 10.1016/ j.envres.2005.06.003

73. Choudhury C, Mazumder R, Kumar R, Dhar B, Sengupta M. Cadmium Induced Oxystress Alters Nrf2-Keap1 Signaling and Triggers Apoptosis in Piscine Head Kidney Macrophages. Aquat Toxicol (2021) 231:105739. doi: 10.1016/j.aquatox.2020.105739

74. Choudhury C, Mazumder R, Biswas R, Sengupta M. Cadmium Exposure Induces Inflammation Through the Canonical NF- $\kappa \mathrm{B}$ Pathway in Monocytes/Macrophages of Channa Punctatus Bloch. Fish Shellfish Immunol (2021) 110:116-26. doi: 10.1016/j.fsi.2021.01.002

75. Demenesku J, Mirkov I, Ninkov M, Popov Aleksandrov A, Zolotarevski L, Kataranovski D, et al. Acute Cadmium Administration to Rats Exerts Both Immunosuppressive and Proinflammatory Effects in Spleen. Toxicology (2014) 326:96-108. doi: 10.1016/j.tox.2014.10.012

76. Chowdhury BA, Chandra RK. Effect of Zinc Administration on CadmiumInduced Suppression of Natural Killer Cell Activity in Mice. Immunol Lett (1989) 22(4):287-91. doi: 10.1016/0165-2478(89)90167-3

77. Cifone MG, Alesse E, Di Eugenio R, Napolitano T, Morrone S, Paolini R, et al. In Vivo Cadmium Treatment Alters Natural Killer Activity and Large Granular Lymphocyte Number in the Rat. Immunopharmacology (1989) 18 (3):149-56. doi: 10.1016/0162-3109(89)90012-X

78. Turley AE, Zagorski JW, Kennedy RC, Freeborn RA, Bursley JK, Edwards JR, et al. Chronic Low-Level Cadmium Exposure in Rats Affects Cytokine Production by Activated T Cells. Toxicol Res (Camb) (2019) 8(2):227-37. doi: $10.1039 / \mathrm{c} 8 \mathrm{tx} 00194 \mathrm{~d}$

79. Ohsawa M, Sato K, Takahashi K, Ochi T. Modified Distribution of Lymphocyte Subpopulation in Blood and Spleen From Mice Exposed to Cadmium. Toxicol Lett (1983) 19(1):29-35. doi: 10.1016/0378-4274(83)90258-8

80. Dzik S. Decoding the Patterns of Self and Nonself by the Innate Immune System. Transfus Med Rev (2002) 16(4):331-2. doi: 10.1053/tmrv.2002. 35325

81. Razzuoli E, Mignone G, Lazzara F, Vencia W, Ferraris M, Masiello L, et al. Impact of Cadmium Exposure on Swine Enterocytes. Toxicol Lett (2018) 287:92-9. doi: 10.1016/j.toxlet.2018.02.005

82. Charles M. M1 and M2 Macrophages: Oracles of Health and Disease. Crit Rev Immunol (2012) 32(6):463-88. doi: 10.1615/critrevimmunol.v32.16.10

83. Hu Q, Lyon CJ, Fletcher JK, Tang W, Wan M, Hu TY. Extracellular Vesicle Activities Regulating Macrophage- and Tissue-Mediated Injury and Repair Responses. Acta Pharm Sin B (2020) 11(6):1493-512. doi: 10.1016/ j.apsb.2020.12.014

84. Okoko T, Awhin EP. Glycine Reduces Cadmium-Induced Alterations in the Viability and Activation of Macrophage U937 Cells. Food Chem Toxicol (2010) 48(2):536-8. doi: 10.1016/j.fct.2009.11.027

85. Grasseschi RM, Ramaswamy RB, Levine DJ, Klaassen CD, Wesselius LJ. Cadmium Accumulation and Detoxification by Alveolar Macrophages of Cigarette Smokers. Chest (2003) 124(5):1924-8. doi: 10.1378/ chest.124.5.1924

86. Sadowska-Woda I, Popowicz D, Karowicz-Bilińska A. Bifenthrin-Induced Oxidative Stress in Human Erythrocytes In Vitro and Protective Effect of Selected Flavonols. Toxicol Vitro (2010) 24(2):460-4. doi: 10.1016/ j.tiv.2009.09.024

87. Ambarus CA, Krausz S, van Eijk M, Hamann J, Radstake TRDJ, Reedquist KA, et al. Systematic Validation of Specific Phenotypic Markers for In Vitro Polarized Human Macrophages. J Immunol Methods (2012) 375(1):196-206. doi: 10.1016/j.jim.2011.10.013

88. Olszowski T, Gutowska I, Baranowska-Bosiacka I, Lukomska A, Drozd A, Chlubek D. Cadmium Alters the Concentration of Fatty Acids in THP-1 Macrophages. Biol Trace Elem Res (2018) 182(1):29-36. doi: 10.1007/ s12011-017-1071-6
89. Cheng Y, Feng Y, Xia Z, Li X, Rong J. $\omega$-Alkynyl Arachidonic Acid Promotes Anti-Inflammatory Macrophage M2 Polarization Against Acute Myocardial Infarction Via Regulating the Cross-Talk Between PKM2, HIF-1 $\alpha$ and iNOS. Biochim Biophys Acta (BBA) - Mol Cell Biol Lipids (2017) 1862 (12):1595-605. doi: 10.1016/j.bbalip.2017.09.009

90. Akiko I, Ruslan M. Control of Adaptive Immunity by the Innate Immune System. Nat Immunol (2015) 16(4):343-53. doi: 10.1007/s11434-016-1105-z

91. Carnevale S, Ghasemi S, Rigatelli A, Jaillon S. The Complexity of Neutrophils in Health and Disease: Focus on Cancer. Semin Immunol (2020) 48:101409. doi: 10.1016/j.smim.2020.101409

92. Yao HD, Wu Q, Zhang ZW, Zhang JL, Li S, Huang JQ, et al. Gene Expression of Endoplasmic Reticulum Resident Selenoproteins Correlates With Apoptosis in Various Muscles of Se-Deficient Chicks. J Nutr (2013) 143(5):613-9. doi: 10.3945/jn.112.172395

93. Diaz-Salazar C, Sun JC. Natural Killer Cell Responses to Emerging Viruses of Zoonotic Origin. Curr Opin Virol (2020) 44:97-111. doi: 10.1016/ j.coviro.2020.07.003

94. Arico E, Wang E, Tornesello ML, Tagliamonte M, Lewis GK, Marincola FM, et al. Immature Monocyte Derived Dendritic Cells Gene Expression Profile in Response to Virus-Like Particles Stimulation. J Transl Med (2005) 3:45. doi: 10.1186/1479-5876-3-45

95. Zhang LW, Bäumer W, Monteiro-Riviere NA. Cellular Uptake Mechanisms and Toxicity of Quantum Dots in Dendritic Cells. Nanomedicine (2011) 6 (5):777-91. doi: 10.2217/nnm.11.73

96. Banchereau J, Steinman R. Dendritic Cells and the Control of Immunity. Nature (1998) 392:245-52. doi: 10.1038/32588

97. Banchereau J, Briere F, Caux C, Davoust J, Lebecque S, Liu Y. Immunobiology of Dendritic Cells. Annu Rev Immunol (2000) 18:767811. doi: 10.1146/annurev.immunol.18.1.767

98. Viau M, Collin-Faure V, Richaud P, Ravanat JL, Candéias SM. Cadmium and T Cell Differentiation: Limited Impact In Vivo But Significant Toxicity in Fetal Thymus Organ Culture. Toxicol Appl Pharmacol (2007) 223(3):25766. doi: 10.1016/j.taap.2007.05.017

99. McCall JL, Elliot M, Nowak E, Damron FH, Barnett JB. Prenatal Exposure to Cadmium Alters the Transciptome of Regulatory T Cells in C57BL/6 Mice and may Contribute to Immunological Health of the Offspring. J Immunol (2018) 200(1 Supplement):110.14.

100. Zeng Q, Zhang W-X, Zheng T-Z, Zhou B, Li J-X, Zhang B, et al. Prenatal and Postnatal Cadmium Exposure and Cellular Immune Responses Among PreSchool Children. Environ Int (2020) 134:105282. doi: 10.1016/ j.envint.2019.105282

101. Wang P, Wang J, Sun YJ, Yang L, Wu YJ. Cadmium and Chlorpyrifos Inhibit Cellular Immune Response in Spleen of Rats. Environ Toxicol (2017) 32 (7):1927-36. doi: 10.1002/tox.22415

102. Balter NJ, Nieder WS, Gray I. Strain Variations in Cadmium-Induced Suppression of Lymphocyte Transformation in Mice. Immunopharmacology (1982) 5(2):111-21. doi: 10.1016/0162-3109(82)90042-x

103. Ohsawa M, Masuko-Sato K, Takahashi K, Otsuka F. Strain Differences in Cadmium-Mediated Suppression of Lymphocyte Proliferation in Mice. Toxicol Appl Pharmacol (1986) 84(2):379-88. doi: 10.1016/0041-008X(86) 90146-8

104. Saggu S, Rehman H, Aziz AT, Alzeibr FMA, Oyouni AAA, Zidan N, et al. Cymbopogon Schoenanthus (Ethkher) Ameliorates Cadmium Induced Toxicity in Swiss Albino Mice. Saudi J Biol Sci (2019) 26(7):1875-81. doi: 10.1016/j.sjbs.2017.01.002

105. Zhang Y, Liu Q, Yin H, Li S. Cadmium Exposure Induces Pyroptosis of Lymphocytes in Carp Pronephros and Spleens by Activating NLRP3. Ecotoxicol Environ Saf (2020) 202:110903. doi: 10.1016/j.ecoenv.2020.110903

106. Yiming Z, Hang Y, Bing S, Hua X, Bo H, Honggui L, et al. Antagonistic Effect of VDR/CREB1 Pathway on Cadmium-Induced Apoptosis in Porcine Spleen. Ecotoxicol Environ Saf (2021) 209:111819. doi: 10.1016/ j.ecoenv.2020.111819

107. Xin C, Guangliang S, Qing Z, Qingqing L, Hang Y, Yiming Z, et al. Astilbin Protects Chicken Peripheral Blood Lymphocytes From Cadmium-Induced Necroptosis Via Oxidative Stress and the PI3K/Akt Pathway. Ecotoxicol Environ Saf (2020) 190:110064. doi: 10.1016/j.ecoenv.2019.110064

108. Zhao Y, Li Q, Yang Z, Shao Y, Xue P, Qu W, et al. Cadmium Activates Noncanonical Wnt Signaling to Impair Hematopoietic Stem Cell 
Function in Mice. Toxicol Sci (2018) 165(1):254-66. doi: 10.1093/toxsci/ kfy166

109. Dan G, Lall SB, Rao DN. Humoral and Cell Mediated Immune Response to Cadmium in Mice. Drug Chem Toxicol (2000) 23:349-60. doi: 10.1081/dct100100120

110. Carey JB, Allshire A, van Pelt FN. Immune Modulation by Cadmium and Lead in the Acute Reporter Antigen-Popliteal Lymph Node Assay. Toxicol Sci (2006) 91(1):113-22. doi: 10.1093/toxsci/kfj142

111. Sugimoto T, Ide-Ektessabi A, Ishihara R, Tanigaki M. An Investigation of Changes in Element Distribution and Chemical States During Differentiation of Embryonic Stem Cells. J Electron Spectrosc Relat Phenomena (2004) 137140:831-8. doi: 10.1016/j.elspec.2004.02.151

112. Zhang D, Zhang T, Liu J, Chen J, Li Y, Ning G, et al. Zn SupplementAntagonized Cadmium-Induced Cytotoxicity in Macrophages In Vitro: Involvement of Cadmium Bioaccumulation and Metallothioneins Regulation. J Agric Food Chem (2019) 67(16):4611-22. doi: 10.1021/ acs.jafc.9b00232

113. Wang H-R, Che Y-H, Wang Z-H, Zhang B-N, Huang D, Feng F, et al. The Multiple Effects of Hydrogen Sulfide on Cadmium Toxicity in Tobacco may be Interacted With CaM Signal Transduction. J Hazard Mater (2021) 403:123651. doi: 10.1016/j.jhazmat.2020.123651

114. Bourque C, Zhang Y, Fu M, Racine M, Greasley A, Pei Y, et al. H2S Protects Lipopolysaccharide-Induced Inflammation by Blocking NFKB Transactivation in Endothelial Cells. Toxicol Appl Pharmacol (2018) 338:20-9. doi: 10.1016/j.taap.2017.11.004

115. Drake EN. Cancer Chemoprevention: Selenium as a Prooxidant, Not an Antioxidant. Med Hypotheses (2006) 67(2):318-22. doi: 10.1016/ j.mehy.2006.01.058

116. Zheng L, Feng L, Jiang W-D, Wu P, Tang L, Kuang S-Y, et al. Selenium Deficiency Impaired Immune Function of the Immune Organs in Young Grass Carp (Ctenopharyngodon Idella). Fish Shellfish Immunol (2018) 77:53-70. doi: 10.1016/j.fsi.2018.03.024

117. McKenzie RC, Rafferty TS, Beckett GJ. Selenium: An Essential Element for Immune Function. Immunol Today (1998) 19(8):342-5. doi: 10.1016/S01675699(98)01294-8

118. Miletić D, Turło J, Podsadni P, Sknepnek A, Szczepańska A, Klimaszewska $M$, et al. Production of Bioactive Selenium Enriched Crude Exopolysaccharides Via Selenourea and Sodium Selenite Bioconversion Using Trametes Versicolor. Food Biosci (2021) 42:101046. doi: 10.1016/ j.fbio.2021.101046

119. Ge J, Guo K, Zhang C, Talukder M, Lv M-W, Li J-Y, et al. Comparison of Nanoparticle-Selenium, Selenium-Enriched Yeast and Sodium Selenite on the Alleviation of Cadmium-Induced Inflammation Via NF-kB/IкB Pathway in Heart. Sci Total Environ (2021) 773:145442. doi: 10.1016/j.scitotenv. 2021.145442

120. Zhang J, Zheng S, Wang S, Liu Q, Xu S. Cadmium-Induced Oxidative Stress Promotes Apoptosis and Necrosis Through the Regulation of the miR-216aPI3K/AKT Axis in Common Carp Lymphocytes and Antagonized by Selenium. Chemosphere (2020) 258:127341. doi: 10.1016/j.chemosphere. 2020.127341

121. Teplický T, Kalafutová A, Jerigová M, Čunderlíková B. Modulation of Aminolevulinic Acid-Based Photoinactivation Efficacy by Iron In Vitro Is Cell Type Dependent. J Photochem Photobiol B: Biol (2020) 213:112048. doi: 10.1016/j.jphotobiol.2020.112048

122. Recalcati S, Locati M, Cairo G. Systemic and Cellular Consequences of Macrophage Control of Iron Metabolism. Semin Immunol (2012) 24(6):3938. doi: 10.1016/j.smim.2013.01.001

123. Gutiérrez-Segura E, Solache-Ríos M, Colín-Cruz A, Fall C. Adsorption of Cadmium by $\mathrm{Na}$ and Fe Modified Zeolitic Tuffs and Carbonaceous Material From Pyrolyzed Sewage Sludge. J Environ Manage (2012) 97:6-13. doi: 10.1016/j.jenvman.2011.11.010

124. Zhang X, Qi Y, Chen Z, Song N, Li X, Ren D, et al. Evaluation of Fluoride and Cadmium Adsorption Modification of Corn Stalk by Aluminum Trichloride. Appl Surf Sci (2021) 543:148727. doi: 10.1016/j.apsusc.2020.148727

125. Poljsak B, Suput D, Milisav I. Achieving the Balance Between ROS and Antioxidants: When to Use the Synthetic Antioxidants. Oxid Med Cell Longev (2013) 2013:956792. doi: 10.1155/2013/956792
126. Um Y, Eo HJ, Kim HJ, Kim K, Jeon KS, Jeong JB. Wild Simulated Ginseng Activates Mouse Macrophage, RAW264.7 cells Through TRL2/4-Dependent Activation of MAPK, NF- $\mathrm{\kappa B}$ and PI3K/AKT Pathways. J Ethnopharmacol (2020) 263:113218. doi: 10.1016/j.jep.2020.113218

127. Fan H-H, Zhu L-B, Li T, Zhu H, Wang Y-N, Ren X-L, et al. Hyperoside Inhibits Lipopolysaccharide-Induced Inflammatory Responses in Microglial Cells Via P38 and NFkB Pathways. Int Immunopharmacol (2017) 50:14-21. doi: 10.1016/j.intimp.2017.06.004

128. Yin B, Di L, Tang S, Bao E. Vitamin CNa Enhances the Antioxidant Ability of Chicken Myocardium Cells and Induces Heat Shock Proteins to Relieve Heat Stress Injury. Res Vet Sci (2020) 133:124-30. doi: 10.1016/ j.rvsc.2020.09.008

129. Fawzi WW, Msamanga GI, Spiegelman D, Urassa EJN, McGrath N, Mwakagile D, et al. Randomised Trial of Effects of Vitamin Supplements on Pregnancy Outcomes and T Cell Counts in HIV-1-Infected Women in Tanzania. Lancet (1998) 351(9114):1477-82. doi: 10.1016/s0140-6736(98) 04197-x

130. Alshatwi AA, Hasan TN, Alqahtani AM, Syed NA, Shafi G, Al-Assaf AH, et al. Delineating the Anti-Cytotoxic and Anti-Genotoxic Potentials of Catechin Hydrate Against Cadmium Toxicity in Human Peripheral Blood Lymphocytes. Environ Toxicol Pharmacol (2014) 38(2):653-62. doi: 10.1016/ j.etap.2014.07.013

131. Kairisalo M, Bonomo A, Hyrskyluoto A, Mudò G, Belluardo N, Korhonen L, et al. Resveratrol Reduces Oxidative Stress and Cell Death and Increases Mitochondrial Antioxidants and XIAP in PC6.3-Cells. Neurosci Lett (2011) 488(3):263-6. doi: 10.1016/j.neulet.2010.11.042

132. Sun X, Yue SZ, Qiao YH, Sun ZJ, Wang C, Li HF. Dietary Supplementation With Selenium-Enriched Earthworm Powder Improves Antioxidative Ability and Immunity of Laying Hens. Poult Sci (2020) 99(11):5344-9. doi: 10.1016/j.psj.2020.07.030

133. Wang Y, Chen H, Chang W, Chen R, Xu S, Tao D. Protective Effects of Selenium Yeast Against Cadmium-Induced Necroptosis Via Inhibition of Oxidative Stress and MAPK Pathway in Chicken Liver. Ecotoxicol Environ Saf (2020) 206:111329. doi: 10.1016/j.ecoenv.2020.111329

134. Tong C, Li P, Yu L-H, Li L, Li K, Chen Y, et al. Selenium-Rich Yeast Attenuates Ochratoxin A-Induced Small Intestinal Injury in Broiler Chickens by Activating the Nrf2 Pathway and Inhibiting NF-KB Activation. J Funct Foods (2020) 66:103784. doi: 10.1016/j.jff.2020. 103784

135. Abbaszadeh S, Yadegari P, Imani A, Taghdir M. Vitamin D3 Protects Against Lead-Induced Testicular Toxicity by Modulating Nrf2 and NF- $\kappa B$ Genes Expression in Rat. Reprod Toxicol (2021) 103:36-45. doi: 10.1016/ j.reprotox.2021.05.008

136. Das B, Maity PC, Sil AK. Vitamin C Forestalls Cigarette Smoke Induced NFKB Activation in Alveolar Epithelial Cells. Toxicol Lett (2013) 220(1):76-81. doi: 10.1016/j.toxlet.2013.04.009

137. Glauert HP. Vitamin E and NF- $\mathrm{kB}$ Activation: A Review. Vitam Horm (2007) 76:135-53. Academic Press. doi: 10.1016/S0083-6729(07)76006-5

138. Alkharashi NAO, Periasamy VS, Athinarayanan J, Alshatwi AA. Sulforaphane Mitigates Cadmium-Induced Toxicity Pattern in Human Peripheral Blood Lymphocytes and Monocytes. Environ Toxicol Pharmacol (2017) 55:223-39. doi: 10.1016/j.etap.2017.08.026

139. Kim J, Sharma RP. Calcium-Mediated Activation of C-Jun NH2-Terminal Kinase (JNK) and Apoptosis in Response to Cadmium in Murine Macrophages. Toxicol Sci (2004) 81(2):518-27. doi: 10.1093/toxsci/ kfh 221

Conflict of Interest: The authors declare that the research was conducted in the absence of any commercial or financial relationships that could be construed as a potential conflict of interest.

Copyright (c) 2021 Wang, Sun, Yao, Ba and Wang. This is an open-access article distributed under the terms of the Creative Commons Attribution License (CC BY). The use, distribution or reproduction in other forums is permitted, provided the original author(s) and the copyright owner(s) are credited and that the original publication in this journal is cited, in accordance with accepted academic practice. No use, distribution or reproduction is permitted which does not comply with these terms. 